\title{
Diagenetic Processes in Aquaculture Ponds Showing Metal Accumulation on Shrimp Gills
}

\author{
Hugues Lemonnier ${ }^{1 *}$, Florence Royer ${ }^{1}$, Florian Caradec ${ }^{2}$, Etienne Lopez', \\ Clarisse Hubert ${ }^{1,3}$, Émilie Rabiller ${ }^{2}$, Térence Desclaux ${ }^{1}$, Jean-Michel Fernandez ${ }^{4}$ and \\ Françoise Andrieux-Loyer ${ }^{2}$
}

1 Ifremer, IRD, Univ Nouvelle-Calédonie, Univ La Réunion, UMR 92200 ENTROPIE, Nouméa, France, ${ }^{2}$ Ifremer - DYNECO PELAGOS, ZI Pointe du Diable, Plouzané, France, ${ }^{3}$ Ifremer - Station de Sète, Sète Cedex, France, ${ }^{4}$ AEL - Pépinière d'Entreprises IRD Promenade Laroque, Nouméa, France

\section{OPEN ACCESS}

Edited by:

António V. Sykes,

University of Algarve, Portugal

Reviewed by:

$\mathrm{Li} \mathrm{Li}$,

Ocean University of China, China

Khor Waiho,

University of Malaysia Terengganu,

Malaysia

*Correspondence:

Hugues Lemonnier

hugues.lemonnier@ifremer.fr

Specialty section:

This article was submitted to

Marine Fisheries, Aquaculture and Living Resources,

a section of the journal

Frontiers in Marine Science

Received: 03 November 2020

Accepted: 13 January 2021

Published: 09 February 2021

Citation:

Lemonnier H, Royer F, Caradec F

Lopez E, Hubert C, Rabiller É,

Desclaux T, Fernandez J-M and

Andrieux-Loyer F (2021) Diagenetic

Processes in Aquaculture Ponds

Showing Metal Accumulation on

Shrimp Gills.

Front. Mar. Sci. 8:625789.

doi: 10.3389/fmars.2021.625789
The gill is the organ by which many toxic metals are taken up by crustaceans. Iron is known to precipitate at its surface, a phenomenon recently observed in some tropical aquaculture ponds. The present study uses a field approach to understand better the environmental conditions and ecological processes involved in this deposit. Because shrimp are exposed to reduced products originating from organic waste accumulated in the sediment, spatial variation in $\mathrm{pH}$, redox potential and concentrations of dissolved metals in pore water were investigated in these ponds. Total organic carbon, acid volatile sulfide and pyrite were also analyzed in the solid phase. $\mathrm{Fe}^{2+}$ in pore waters showed high spatial variability between ponds and within the same pond with concentrations up to $1,193 \mu \mathrm{mol} \mathrm{I}^{-1}$. Behaviors of $\mathrm{Fe}^{2+}, \mathrm{Mn}^{2+}$ and $\mathrm{Co}^{2+}$ in pore water were similar. Four geochemical environments were identified, based on their physico-chemical characteristics. Highest concentrations for $\mathrm{Fe}^{2+}, \mathrm{Mn}^{2+}$ and $\mathrm{Co}^{2+}$ in sediment pore water occurred in slightly acidic and suboxic conditions. When the sediment became anoxic, the $\mathrm{H}_{2} \mathrm{~S}$ produced reacted with $\mathrm{Fe}^{2+}$ and/or $\mathrm{Co}^{2+}$ to form acid volatile sulfide and pyrite. When $\mathrm{pH}$ increased, the concentration of free $\mathrm{H}_{2} \mathrm{~S}$ rose up to $736 \mu \mathrm{mol}$ $I^{-1}$. With neutral and suboxic conditions, dissolved metal concentrations could be controlled by their precipitation as oxides and hydroxides. The production of pyrite suggested the existence of a possible process of sediment acidification between two crop periods through the production of sulfuric acid. This acidification could increase with pond age and be the cause of the accumulation of reduced metal after 30 years of aquaculture activity.

Keywords: Shrimp aquaculture sustainability, iron deposits, gills, sediment acidification, redox dynamic, dynamic of metals, pyrite

\section{INTRODUCTION}

Aquatic organisms have the ability to accumulate metals from different sources, including sediment and water. Gills, a sensitive organ involved in the respiration and osmoregulation processes, are the first point of contact between waterborne metal and the animal, and is continuously exposed to ambient water. Ferrous iron $\left(\mathrm{Fe}^{2+}\right)$ is known to precipitate on the gills of aquatic organisms because the gill microenvironment is characterized by specific conditions such as $\mathrm{pH}$ that differ from the surrounding environment (Peuranen et al., 1994). Iron accumulates in the 
form of ferrihydrite in the gill chambers, as already reported for the shrimp Rimicaris exoculata, which dominates the megafauna of some of the hydrothermal vent sites on the Mid-Atlantic Ridge (Zbinden et al., 2004).

The lagoon of New Caledonia is subjected to a high degree of metal contamination pressure (Grenz et al., 2013). Mining activities represent the first economical resource of this island and open-cast mining exploitations increase the metal discharge into the lagoon waters implying a contamination of the coastal environment. For 15 years, an increasing attention has been given to the assessment of the metal behavior in marine organisms (Metian et al., 2008; Hédouin et al., 2009; Briand et al., 2014; Marchand et al., 2016). More recently, shrimps with orange gills (OG) were observed in certain earthen grow-out ponds and up to $70 \%$ of the animals of the population in a given pond could be affected. This coloration has affected product quality in the processing plant, leading to lower-value shrimp for farmers. Histological, biochemical and scanning electron microscopy studies have shown that iron layers settle on the tissue surface in a heterogeneous way and that the iron concentration was six times higher in OG than in white gills (Wabete et al., 2015). However, iron was not the only metal that accumulated on the surface of gills and other metals such as cobalt and chromium were also shown to be higher in the whole tissue. As observed in $R$. exoculata, the color resulted from the accumulation of iron oxides and the coloration intensity varied according to the intermolt stages, ranging from white in the postmolt stage to a deep orange in the premolt stage, which then disappeared after molting (Wabete et al., 2015). The OG phenomenon was noticeable when the average weight of shrimp is higher than $10 \mathrm{~g}$, after 10 weeks of rearing when feeding rates were higher than 6-7 $\mathrm{gm}^{-2} \mathrm{day}^{-1}$. The percentages of animals with OG in the population of a same pond varied greatly from week to week until the end of the rearing.

Aquaculture ponds receive organic matter (OM) input to feed the animals, and the amount increases with time and weight gain. A significant proportion of nitrogen (40\%) added to ponds is not recovered in harvested shrimp but is found in the bottom sediments of the pond (Martin et al., 1998). Typically, the system exhibits fast eutrophication, driven mainly by this feed input and sediment resuspension through shrimp bioturbation (Lemonnier et al., 2017). Consequently, ponds exhibit high levels of primary production in the water column and at the interface with the sediment (Burford et al., 2003; Hochard et al., 2019). Sediments in this environment are characterized by enhanced organic matter flux generated both by unconsumed feed and shrimp feces and by sedimentation from the overlying high productive water column.

A high level of heterogeneity at the pond bottom occurs with accumulated and eroded sediment areas during rearing. These erosion processes lead to a high variability in soil characteristics (organic matter, $\mathrm{pH}$, redox, etc.) and the sediment print reflects the hydrodynamics of the pond, with mineral and organic particles settling when the water current slows (Avnimelech and Ritvo, 2003). In shrimp ponds in New Caledonia, our previous studies using both field and experimental approaches suggested that sediment became heterotrophic, as the daily feed supply was around $5.0 \mathrm{~g} \mathrm{~m}^{-2}$ day $^{-1}$ (Luong et al.,
2014, 2016; Hochard et al., 2019). More generally, the whole ecosystem (sediment + water column) became heterotrophic, when daily feed supply was higher than $7.0 \mathrm{~g} \mathrm{~m}^{-2} \mathrm{day}^{-1}$. The accumulation of sedimentary organic matter generated strong reducing conditions that directly affected diagenetic processes in ponds, favoring suboxic and anoxic processes in which $\mathrm{Fe}$ and $\mathrm{SO}_{4}{ }^{2-}$ reduction pathways were important for organic matter decomposition. Redox potential (Eh) was shown in aquaculture ponds to decrease with time to $-50 \mathrm{mV}$ after 9 weeks of rearing (Hochard et al., 2019). Because OG appeared after 10 weeks, these environments characterized by heterotrophic conditions were likely to be a factor accounting for the occurrence of this metal accumulation. Animals kept out of contact with pond sediment during rearing showed a decrease in OG intensity, suggesting a link with the sediment biogeochemistry (Wabete et al., 2015). Moreover, a preliminary study of reduced iron in pore water during OG period showed high concentrations (up to $70 \mu \mathrm{mol} \mathrm{l}^{-1}$ ) similar to the values reported for the environment of Rimicaris exoculata by Zbinden et al. (2004).

However, as feed management was similar between ponds and between farms including farms with no OG, other environmental factors were likely be involved in accounting for differences in OG development. The first aim of this study was to confirm the presence of reduced metals (Fe, Mn, and Co) at the water-sediment interface where shrimp live, on the assumption of a cause-and-effect relationship between reduced iron concentration in pore water and OG development. The second was to analyze the environmental conditions and identify the diagenetic processes in ponds implied in the production of reduced metals. To conclude, the OG-inducing risk factors are listed.

\section{MATERIALS AND METHODS}

\section{The Study Site}

The farm was located in Teremba Bay (TE; $24^{\circ} 44^{\prime} 59.01^{\prime \prime} \mathrm{S}$; $165^{\circ} 41^{\prime} 48.93^{\prime \prime} \mathrm{E}$ ) on the west coast of the island. Fourteen earthen ponds of about 10 ha each were built behind the mangrove forest on salt marsh in 1983 (Figure 1). This shrimp farm was the largest in New Caledonia, with an area of 133 ha. All the ponds were managed by the farmer using standard techniques and stocked with blue shrimp Litopenaeus stylirostris at densities ranging between 15 and 25 shrimp $\mathrm{m}^{-2}$. The first harvest occurred after about 120 rearing days, when the weight of the animals was around $20 \mathrm{~g}$. Shrimp were fed daily with locally produced pellets, including $40 \%$ of crude proteins. This study was conducted at the end of March and beginning of April 2017 in three ponds, designated A, E, and W, which were dried for one month before filling with seawater. Sediment grain size on the pond bottom lay predominantly within the silty clay fraction, and sediment organic content ranged generally between 0.5 and 5.0\% (Lemonnier et al., 2004b). The ponds (A: 9.2 ha, E: 10 ha, $\mathrm{W}$ : $10.1 \mathrm{ha}$; and about $1 \mathrm{~m}$ depth) were supplied with postlarvae (0.03 g) in September 2017 (W) and November 2017 (A and E). Water flowing by gravity through all ponds was pumped from the adjacent bay. Daily water exchange rate was similar 


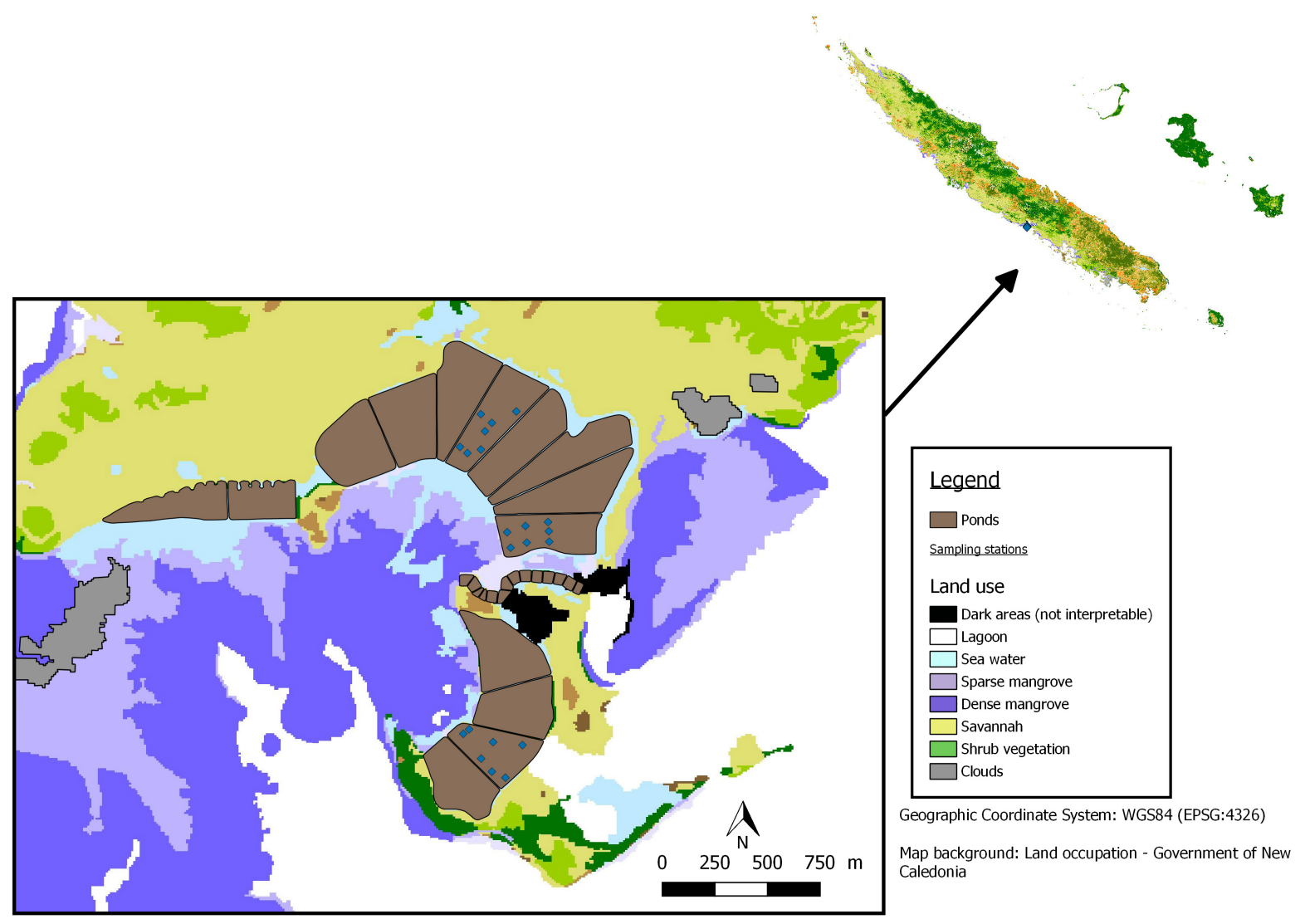

FIGURE 1 | Map showing the location of sampling stations in the three ponds built in 1983 behind the mangrove of Teremba Bay (New Caledonia).

between ponds and varied between 5 and $40 \%$ of the total pond volume, depending on the shrimp biomass. The ponds were aerated using paddlewheels.

To track the temporal variability of the proportion of shrimp affected by OG, surveys were conducted in all ponds by the farm's technical staff. Shrimp sampling was carried out once a week. More than one hundred shrimp were caught quickly using a castnet in several different locations in the pond (from 4 to 8 ), designated as representative of the pond by the farmers. Shrimps were pooled, weighed and examined to assess the proportion of colored gills in the population.

\section{Samplings and Field Analyses}

Nineteen stations were selected in three ponds for a better understanding of the effect of organic matter distribution on diagenetic processes (Figure 1). One undisturbed large core (40 $\mathrm{cm}$ long and $10 \mathrm{~cm}$ diameter) with overlying water was manually collected at each station by a diver using a manual corer to minimize sediment disturbance. $\mathrm{pH}_{\text {in situ }}$ and redox potential (Eh) were assessed at each station at $-1 \mathrm{~cm}$ following to the method described by Hussenot and Martin (1995), by inserting electrodes into the sediment.

Pore water was immediately extracted after coring at $-1 \mathrm{~cm}$ using soil moisture rhizons characterized by a vertical resolution of $1 \mathrm{~cm}$ (Seeberg-Elverfeldt et al., 2005). Aliquots were stored at $4^{\circ} \mathrm{C}$ for dissolved metals, sulfides and nutrients.

The first $\mathrm{cm}$ of sediment was collected using a syringe cut at the tip to determine the chl $a$ content at the watersediment interface. Three layers of sediment were collected afterward, corresponding to three horizons named S, M, and P (Munsiri et al., 1995), distinguishable by their textures and color appearances. Horizon S was characterized by dark homogenous black sediment buildup over the grow-out period in progress. Its thickness was generally $2 \mathrm{~cm}$. Horizon $\mathrm{M}$ revealed dark clumps of mud due to the effect of previous pond tilling between crops. Sediment in horizon P collected at the bottom of the core at a depth greater than $5 \mathrm{~cm}$ was light-brown and consisted of "original soil." This last and deepest horizon was considered to be little impacted by aquaculture activity (Munsiri et al., 1995).

Three supplementary undisturbed small cores with overlying water were also manually collected in each pond using syringes cut at the tips $(2.3 \mathrm{~cm}$ diameter; $10 \mathrm{~cm}$ long) at 9 stations (Ab, Ad, Ag, Ea, Ed, Ef, Wa, Wc, and Wd) by a diver, in order to analyze iron bound to acid volatile sulfide (AVS) and chromiumreducible sulfur (CRS). After being collected, syringes were directly closed underwater using airtight caps to limit gaseous exchange, stored at $4^{\circ} \mathrm{C}$ in a cooler and quickly transported to the laboratory. 


\section{Analytical Methods}

\section{Sediment Solid Phase Analyses}

Sediment samples from large cores were weighed, dried at $60^{\circ} \mathrm{C}$ for 1 week to calculate water content, and lightly crushed to pass through a $0.1 \mathrm{~mm}$ sieve to remove shells and stones. $\mathrm{pH}$ measurements were made in 1:1 dry soil to distilled water mixtures $\left(\mathrm{pH}_{1: 1}\right)$ (Thunjai et al., 2001). Samples were analyzed for organic matter by loss on ignition, using a muffle furnace at $350^{\circ} \mathrm{C}$ for $8 \mathrm{~h}$ (Queiroz and Boyd, 1998). The Kjeldhal method was used to determine total nitrogen (TN) (Nelson and Sommers, 1982). Total organic carbon (TOC) was measured by the Walkley-Black potassium dichromate-sulfuric acid oxidation method with external heating (Boyd, 1995). Metals (Fe, Co, and $\mathrm{Mn}$ ) and total phosphorus (TP) were analyzed in sediment by ICP-OES Varian 730-ES after standard alkaline fusion of a $100 \mathrm{mg}$ sample at $1,100^{\circ} \mathrm{C}$ with $1 \mathrm{~g}$ of $\mathrm{Li}_{2} \mathrm{~B}_{4} \mathrm{O}_{7}$ for $20 \mathrm{~min}$. The fusion residue was then dissolved in $5 \% \mathrm{HCl}$. Chlorophyll $a(\mathrm{Chl} a)$ concentration in sediment was analyzed from frozen samples $(1 \mathrm{~cm}$ core layer) collected at each sampling site. Frozen sediment samples were freeze-dried for $24 \mathrm{~h}$ before extraction using methanol. The extract was analyzed before and after acidification using a TD-700 fluorometer (Holm-Hansen et al., 1965 ) in accordance with the method described by Underwood (2002). The concentration of Chl $a$ was expressed in $\mathrm{mg} \mathrm{m}^{-2}$.

To analyze acid volatile sulfide minerals (AVS) and chromiumreducible sulfur (CRS), small cores were cut into three layers (horizons S, M, and P) under nitrogen flow. Each horizon was pooled from the three cores collected at each station and then centrifuged at $1,800 \times g$ to remove water, avoiding any contact of the samples with air. Samples were stored frozen at $-20^{\circ} \mathrm{C}$ prior to analysis. Iron from pyrite $\left(\mathrm{FeS}_{2}\right)$ determination was performed from defrosted sediments by reduction with acidified $\mathrm{Cr}$ (II) according to the method described in Canfield et al. (1986). The Cr-reduction method is specific for reducing inorganic forms of sulfur $\left\{\mathrm{S}-\mathrm{FeS}_{2}+\mathrm{S}-\mathrm{Fe}-\mathrm{S}+\right.$ elemental sulfur $\left.[\mathrm{S}(0)]\right\}$. As elemental sulfur was shown to be negligible compared to pyrite sulfur in recent sediments (Wilkin et al., 1997) and as the sediment was dried for $24 \mathrm{~h}$ at $80^{\circ} \mathrm{C}$ to remove $\mathrm{FeS}$ in acetone (Rozan et al., 2002), CRS was assumed here to be entirely composed of pyrite. A Jones reduction column was used to reduce $1 \mathrm{M} \mathrm{CrCl}_{3}$ (in 1 $\mathrm{M} \mathrm{HCl})$ to $\mathrm{Cr}(\mathrm{II})$ under inert atmosphere $\left(\mathrm{N}_{2}\right)$ in a glove box. Acid volatile sulfides (AVS $=\mathrm{FeS})$ were extracted under inert atmosphere $\left(\mathrm{N}_{2}\right)$ by adding preweighed $(\sim 1 \mathrm{~g})$ wet defrosted sediment to a cold $6 \mathrm{~N} \mathrm{HCl}$ solution. The bisulfide produced by these two extraction procedures was purged with $\mathrm{N}_{2}$ and trapped as $\mathrm{ZnS}$ precipitates by $20 \mathrm{ml}$ alkaline $\mathrm{ZnAc}$ solutions (ZnAc $0.027 \mathrm{M}+\mathrm{NaOH} 0.075 \mathrm{M}$ for $\mathrm{FeS}_{2} ; \mathrm{ZnAc} 0.005 \mathrm{M}+\mathrm{NaOH}$ $0.05 \mathrm{M}$ for $\mathrm{FeS}$ ) in a separate vial. Hydrogen sulfide trapped was measured using the colorimetric methylene blue method following Fonselius et al. (2007).

\section{Pore Water Analyses}

Dissolved $\mathrm{Fe}^{2+}, \mathrm{Mn}^{2+}$, and $\mathrm{Co}^{2+}$ were analyzed using ICPOES following the procedure described by Moreton et al. (2009). The detection limit of $\mathrm{Co}^{2+}, \mathrm{Fe}^{2+}$, and $\mathrm{Mn}^{2+}$ was $6 \mathrm{ng} \mathrm{l}^{-1}$. Dissolved sulfide was determined by the methylene blue method (Fonselius et al., 2007).

\section{Statistical Analyses}

Variations in all variables were investigated by means of a one-way analysis of variance (ANOVA) with ponds as the major source of variance or by two-way ANOVA, with the horizons ( $\mathrm{S}, \mathrm{M}$, and $\mathrm{P}$ ) and ponds as major sources of variance. Before analysis, data were checked for normal distribution and homogeneity of variance using the Shapiro-Wilk and Bartlett's tests, respectively. If data were not normally distributed, they were corrected for normality using log-transformation, squared, square root or arcsine transforms. If data did not meet the test criteria after appropriate transformations, comparisons were made using Dunn's non-parametric comparison for post hoc testing after a non-parametric Kruskal-Wallis test. Differences were considered significant at $p<0.05$. Correlations between variables were calculated on transformed data using Spearman correlation tests.

\section{RESULTS}

\section{Dynamic of Orange Gills in Shrimp Population}

Animals with OG were observed after 90 days of rearing in the three studied ponds (Figure 2). The proportion of OG in the population showed a similar and complex pattern in the three ponds with succession of increasing and decreasing phases. The mean percentage of animals showing this characteristic was $25 \%$ and reached a peak of $65 \%$ (day 133, pond A). At the time of sampling in pond W $(30 / 03 / 2017$ - day 199), the proportion ranged from 0 and 25\%. This proportion was 59\% (5/04/2017 day 149) and $0 \%(4 / 04 / 2017$ - day 148) for ponds $A$ and E, respectively.

\section{General Sediment Properties}

Water content in sediment ranged between 28 and 74\% (wet weight). Averaged value varied significantly between ponds and horizons (Kruskal-Wallis test, $p<0.01$ ) (Table 1). $\mathrm{pH}$ value measured from dry sediment ranged between 6.7 and 7.7.

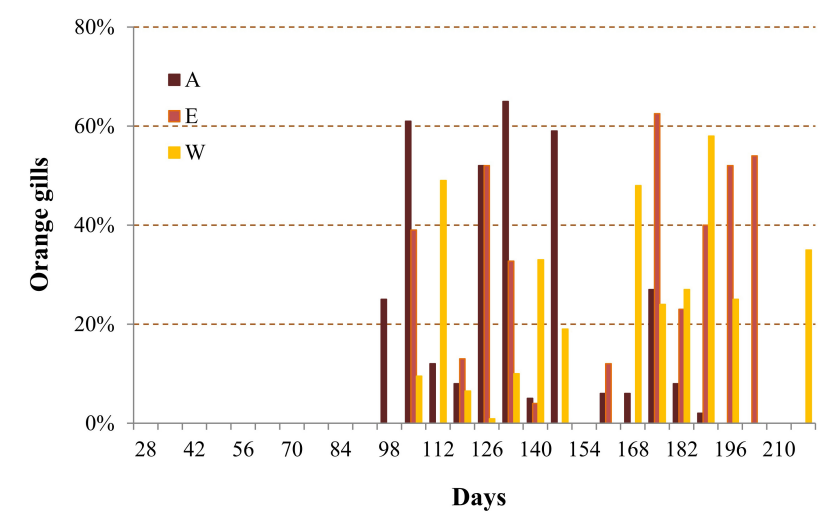

FIGURE 2 | Temporal variations of orange gill percentage in the shrimp population of the three studied ponds (Ponds A, E, and W). 
TABLE 1 | Means \pm SD for the main physical and chemical characteristics of sediment in each horizon (S, M, and P) for the three ponds.

\begin{tabular}{|c|c|c|c|c|c|c|c|}
\hline Pond & Horizon & WC\% (ww) & $\mathrm{pH}_{1: 1}$ & OM \% & TOC $\left(\mathrm{mg} \mathrm{g}^{-1}\right)$ & $\mathrm{TN}\left(\mathrm{mg} \mathrm{g}^{-1}\right)$ & $\mathrm{TP}\left(\mu \mathbf{g} \mathbf{g}^{-1}\right)$ \\
\hline \multirow[t]{3}{*}{ A } & $S$ & $54 \pm 10^{c d}$ & $6.6 \pm 0.2^{A}$ & $4.0 \pm 0.5^{A}$ & $23.6 \pm 4.3^{A}$ & $2.2 \pm 0.3^{A}$ & $1624 \pm 153^{\mathrm{cd}}$ \\
\hline & $\mathrm{M}$ & $41 \pm 3^{a b c}$ & $6.7 \pm 0.2$ & $3.7 \pm 0.3$ & $18.6 \pm 3.3$ & $1.7 \pm 0.1$ & $1722 \pm 128^{d}$ \\
\hline & $P$ & $38 \pm 2^{a b}$ & $6.8 \pm 0.1$ & $3.4 \pm 0.5$ & $15.6 \pm 3.7$ & $1.4 \pm 0.2$ & $1559 \pm 103^{\mathrm{cd}}$ \\
\hline \multirow[t]{3}{*}{$E$} & S & $50 \pm 10^{c d}$ & $7.1 \pm 0.3^{\mathrm{B}}$ & $3.0 \pm 0.6^{\mathrm{B}}$ & $15.7 \pm 5.1^{\mathrm{B}}$ & $1.6 \pm 0.4^{\mathrm{B}}$ & $1534 \pm 412^{b c d}$ \\
\hline & $M$ & $41 \pm 2^{\mathrm{abcd}}$ & $6.7 \pm 0.2$ & $2.8 \pm 0.3$ & $13.0 \pm 2.8$ & $1.3 \pm 0.3$ & $1295 \pm 460^{a b c}$ \\
\hline & $\mathrm{P}$ & $37 \pm 8^{a b}$ & $7.3 \pm 0.3$ & $2.7 \pm 0.6$ & $10.7 \pm 3.4$ & $1.0 \pm 0.2$ & $1002 \pm 485^{a b}$ \\
\hline \multirow[t]{3}{*}{ W } & S & $58 \pm 15^{d}$ & $6.9 \pm 0.3^{B}$ & $3.4 \pm 1.2^{\mathrm{B}}$ & $20.3 \pm 8.7^{B}$ & $2.2 \pm 1.0^{\mathrm{B}}$ & $1876 \pm 730^{\mathrm{cd}}$ \\
\hline & $\mathrm{M}$ & $48 \pm 13^{\mathrm{bcd}}$ & $7.0 \pm 0.2$ & $2.9 \pm 1.0$ & $16.2 \pm 8.6$ & $1.6 \pm 0.9$ & $1575 \pm 504^{\mathrm{cd}}$ \\
\hline & $P$ & $36 \pm 3^{a}$ & $7.1 \pm 0.3$ & $2.5 \pm 0.3$ & $9.4 \pm 2.9$ & $0.9 \pm 0.3$ & $993 \pm 420^{a}$ \\
\hline
\end{tabular}

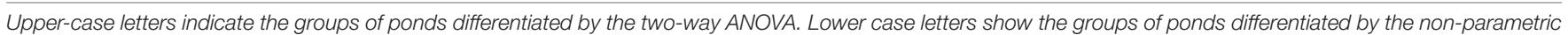
Kruskal-Wallis test. In this last case, data are not normally distributed.

TABLE $2 \mid F$-values from two-way ANOVA.

\begin{tabular}{lccc}
\hline & Pond & Horizon & Pond $\mathbf{x}$ Horizon \\
\hline $\mathrm{pH}_{1: 1}$ & $10.09^{\star \star \star}$ & $6.57^{\star \star \star}$ & 2.27 \\
$\mathrm{OM}$ & $9.09^{\star \star \star}$ & $4.64^{\star}$ & 0.40 \\
$\mathrm{TOC}$ & $7.68^{\star \star \star}$ & $12.36^{\star \star \star}$ & 0.68 \\
$\mathrm{TN}$ & $6.11^{\star \star}$ & $18.43^{\star \star \star}$ & 0.75 \\
$\mathrm{Fe}$ & $11.49^{\star \star \star}$ & $7.43^{\star \star}$ & 0.07 \\
$\mathrm{FeS}_{2}$ & 2.28 & $20.94^{\star \star \star}$ & 0.21 \\
\hline
\end{tabular}

Significant results are indicated by asterisks $\left({ }^{*} p<0.05 ;{ }^{* *} p<0.01 ;{ }^{* * *} p<0.001\right)$; OM, organic matter; TOC, total organic carbon; TN, total nitrogen, Fe, iron; CRS, chromium reducible sulfur $\left(\mathrm{FeS}_{2}\right)$.

The two-way ANOVA showed significant effects of horizon and pond on this parameter, with lower values measured in horizon $S$ compared to horizons $M$ and $P$ (Tables 1, 2). Pond $\mathrm{A}$ had the lowest mean values whatever the horizon (Table 1). In horizon $\mathrm{S}, \mathrm{pH}$ was negatively correlated with $\mathrm{OM}(r=-0.43), \mathrm{C} / \mathrm{N}$ ratio $(r=-0.62)$, COT $(r=-0.43)$ and pheopigments $(r=-0.45)$, and positively correlated with total Mn $(r=0.78)$ (Supplementary Table 1$)$. The percentage of organic matter varied widely in samples from 1.7 to $5.5 \%$. $\mathrm{OM}$ concentration decreased with depth whatever the station, with the lowest concentrations occurring in ponds $\mathrm{E}$ and $\mathrm{W}$ (Tables 1, 2). Total nitrogen, phosphorus and TOC showed a similar pattern to those of $\mathrm{OM}$ and were significantly correlated $(r=0.86)$. Carbon and nitrogen represented $49 \pm 10 \%(n=61)$ and $4.8 \pm 1.1 \%(n=61)$ of the organic matter, respectively (Table 1). Averaged value of the $\mathrm{C} / \mathrm{N}$ ratio for all samples was $12.0 \pm 1.5$ (range: 9.4-17.5). This parameter did not differ between horizons and ponds (two-way ANOVA, $p=0.11$ ). TP concentration decreased with depth in ponds $\mathrm{E}$ and $\mathrm{W}$ but not in pond A (Table 1). Mean value ranged between 1,000 and $1,500 \mu \mathrm{g} \mathrm{g}^{-1}$. Pond $\mathrm{W}$ had the highest values in horizon $\mathrm{S}$ $\left(\right.$ mean $\left.=1,876 \mu \mathrm{g} \mathrm{g}^{-1}\right)$.

Averaged concentrations of metallic compounds in sediment are shown in Table 3 in the order of decreasing concentrations: $\mathrm{Mn}>\mathrm{Fe}>\mathrm{Co}$. Significant differences were observed depending on horizons and ponds (Table 3 and Supplementary Table 1.). $\mathrm{Mn}$ and $\mathrm{Fe}$ were higher in pond $\mathrm{E}$ than in pond $\mathrm{A}$ and $\mathrm{W}$.
TABLE 3 | Means \pm SD expressed in $\mu \mathrm{g} \mathrm{g}^{-1}$ for several metals in each horizon $(\mathrm{S}, \mathrm{M}$, and $\mathrm{P})$ for the three ponds.

\begin{tabular}{|c|c|c|c|c|}
\hline Pond & Horizon & Mn & $\mathrm{Fe}$ & Co \\
\hline \multirow[t]{3}{*}{ A } & S & $184 \pm 6^{a}$ & $50 \pm 1^{\mathrm{A}}$ & $12 \pm 0^{\mathrm{a}}$ \\
\hline & $\mathrm{M}$ & $192 \pm 17^{\mathrm{ab}}$ & $53 \pm 1$ & $14 \pm 1^{\mathrm{ab}}$ \\
\hline & $\mathrm{P}$ & $256 \pm 76^{c}$ & $57 \pm 3$ & $15 \pm 0^{\mathrm{abc}}$ \\
\hline \multirow[t]{3}{*}{$E$} & S & $395 \pm 86^{\text {de }}$ & $56 \pm 9^{B}$ & $17 \pm 2^{a b c}$ \\
\hline & $M$ & $431 \pm 160^{\text {de }}$ & $60 \pm 7$ & $19 \pm 2^{\text {de }}$ \\
\hline & $\mathrm{P}$ & $500 \pm 160^{e}$ & $63 \pm 9$ & $18 \pm 3^{\text {cde }}$ \\
\hline \multirow[t]{3}{*}{ W } & S & $230 \pm 18^{b c}$ & $48 \pm 6^{\mathrm{B}}$ & $19 \pm 2^{\text {de }}$ \\
\hline & $M$ & $252 \pm 40^{\mathrm{cd}}$ & $52 \pm 4$ & $20 \pm 2^{e}$ \\
\hline & $\mathrm{P}$ & $322 \pm 204^{c d}$ & $54 \pm 4$ & $19 \pm 2^{\text {de }}$ \\
\hline
\end{tabular}

Upper-case letters indicate the groups of ponds differentiated by the two-way ANOVA. Lower case letters show the groups of ponds differentiated by Dunn's comparison test after a significant non-parametric Kruskal-Wallis test.

\section{Microphytobenthos}

Mean chl a concentration for each pond varied between $178 \pm 108$ and $378 \pm 123 \mathrm{mg} \mathrm{m}^{-2}$; values ranged from $51 \mathrm{mg}$ $\mathrm{m}^{-2}$ (Pond $\mathrm{W}$, station $\mathrm{g}$ ) to $801 \mathrm{mg} \mathrm{m}^{-2}$ (Pond E, station c). Chl $a$ was negatively correlated with $\mathrm{Cu}(r=-0.58)$, Co $(r=-0.46)$, and positively correlated with $\mathrm{Cr}(r=0.55$ (Supplementary Table1). High chl a concentrations were found in the first $\mathrm{cm}$ of the cores for a $\mathrm{pH}_{\text {in situ }}$ lower than 6.8 and Eh higher than $-100 \mathrm{mV}$ (Figure 3A). Pheophytin concentrations ranging from 153 to $233 \mathrm{mg} \mathrm{m}^{-2}$ (Figure $3 \mathbf{B}$ ) were positively correlated with TOC $(r=0.76)$, TN $(r=0.73)$ and OM $(r=0.59)$ and negatively correlated with Eh $(r=-0.54)$. The one-way ANOVA showed a significant effect of the pond as source of variability, with lower values measured in pond $\mathrm{E}$ than in ponds $\mathrm{A}$ and $\mathrm{W}$. Phaeophytin represented $13-66 \%$ of chl $a$. This ratio was significantly higher in pond $\mathrm{W}(52 \pm 9 \%)$ than in ponds $\mathrm{A}(39 \pm 7 \%)$ and $\mathrm{E}(35 \pm 17 \%)$.

\section{Pore Water Chemistry}

Samples $(n=22)$ showed physicochemical characteristics under the interface $(-1 \mathrm{~cm})$ ranging from 6.3 to 7.2 and from -230 to $+23 \mathrm{mV}$, for $\mathrm{pH}_{\text {in situ }}$ and $\mathrm{Eh}$, respectively. Fifteen stations had slightly acidic conditions $(<7.0)$ and five had stronger acidic conditions with values below 6.5 (2 in pond A and 3 in pond $\mathrm{E})$. Eh mean values were similar in ponds $\mathrm{A}$ 

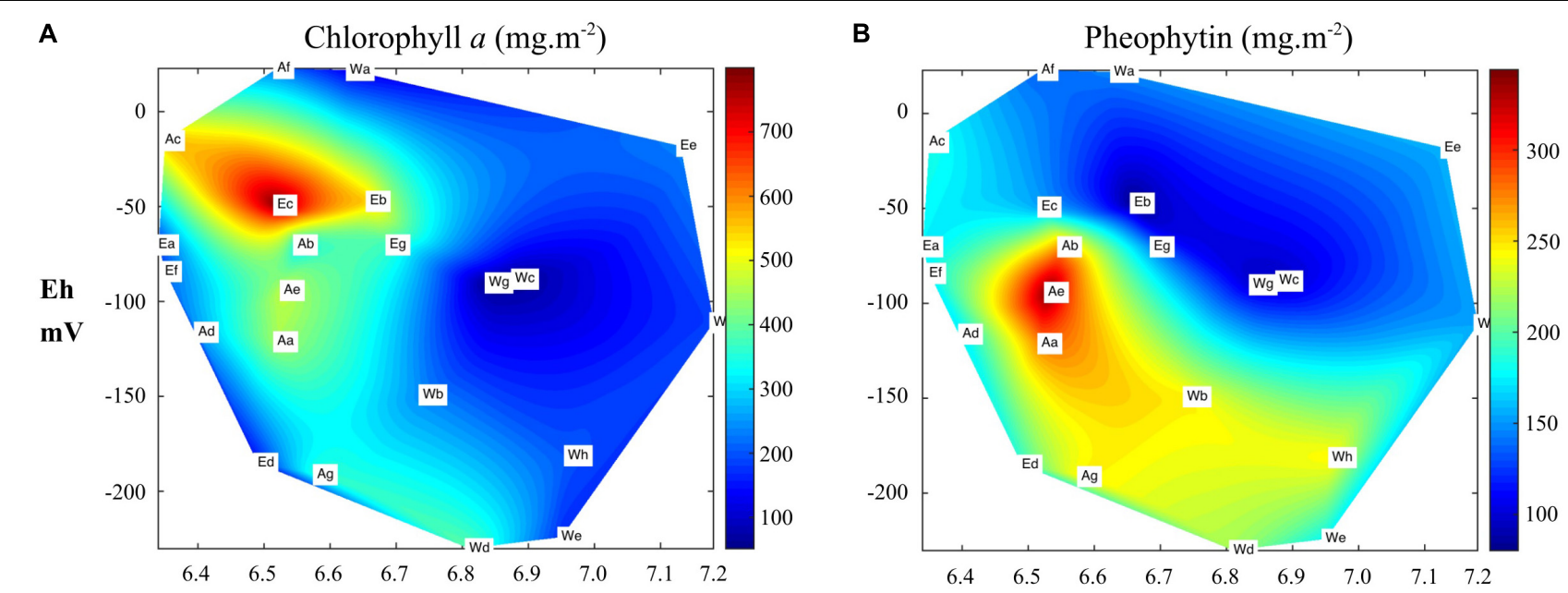

C
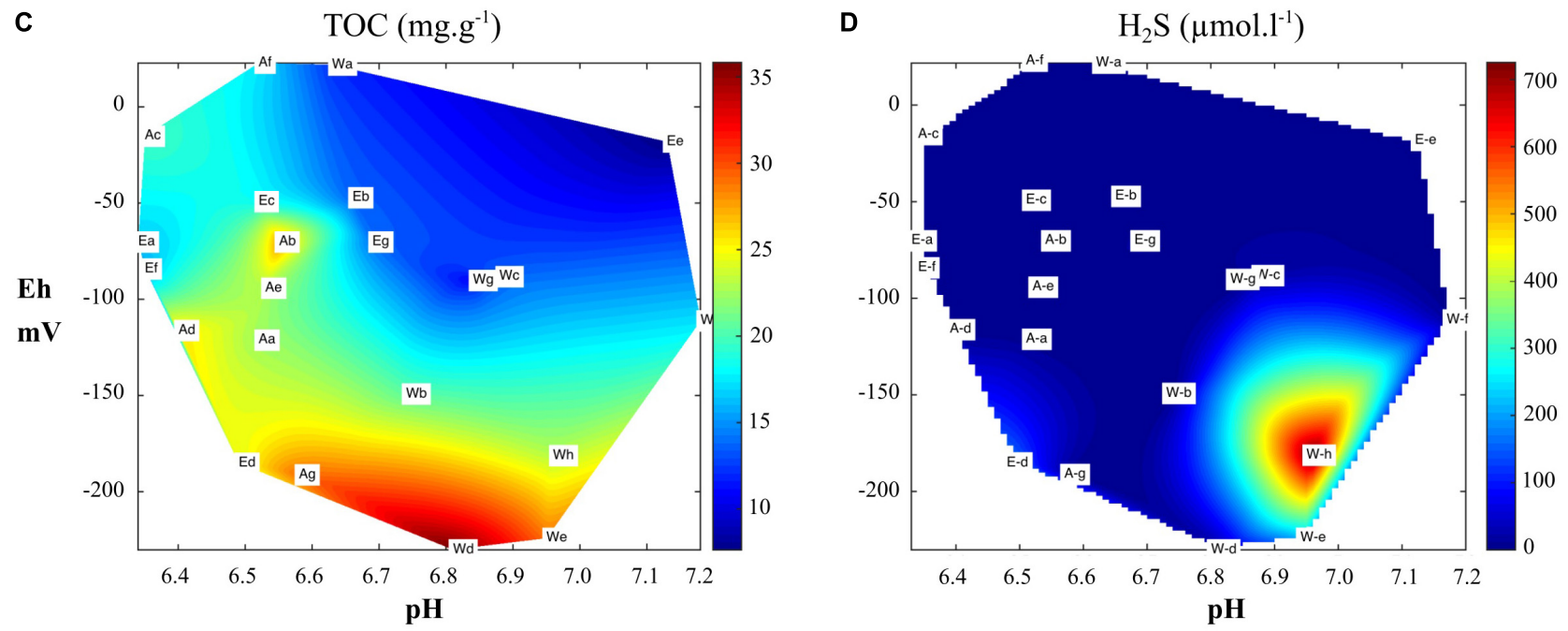

FIGURE 3 | Redox distribution of (A) chlorophyll a, (B) pheophytin, (C) total organic carbon (TOC), and (D) $\mathrm{H}_{2} \mathrm{~S}$ in pore water in relation to the pH as observed in the three ponds in the first $\mathrm{cm}$ of sediment.

and $\mathrm{E}(-84 \pm 71 \mathrm{mV}$ and $-75 \pm 53 \mathrm{mV}$, respectively) and lower in pond $\mathrm{W}(-132 \pm 83 \mathrm{mV})$. This parameter decreased significantly with increased TOC $(r=-0.70)$, TN $(r=-0.71)$ and OM $(r=-0.53)$ (Supplementary Table 1; Figure 3C). $\mathrm{H}_{2} \mathrm{~S}$ concentrations were below $20 \mu \mathrm{mol} \mathrm{l}^{-1}$ except for three stations with values higher than $150 \mu \mathrm{mol} \mathrm{l^{-1 }}$ (Figure 3D). This compound was negatively correlated with Eh $(r=-0.75)$ and positively with TN $(r=0.55)$, TOC $(r=0.58)$ and TP $(r=0.44)$ (Supplementary Table 1). $\mathrm{Fe}^{2+}$ concentrations ranged from quantitative limitation (QL) to $1,193 \mu \mathrm{mol} 1^{-1}$. We observed higher mean values $(F=6.51 ; p<0.01)$ in ponds $\mathrm{A}$ $\left(335 \pm 290 \mu \mathrm{mol} \mathrm{l}^{-1}\right)$ and $\mathrm{E}\left(441 \pm 401 \mu \mathrm{mol} \mathrm{l}{ }^{-1}\right)$ than in pond $\mathrm{W}\left(54 \pm 122 \mu \mathrm{mol} \mathrm{l}^{-1}\right)$. As observed for $\mathrm{Fe}^{2+}$, results showed a significant effect in terms of ponds on $\mathrm{Mn}^{2+}$ and $\mathrm{Co}^{2+}$. Concentrations of these metals were significantly correlated (Supplementary Table 1). The distributions of $\mathrm{Mn}^{2+}, \mathrm{Fe}^{2+}$, and $\mathrm{Co}^{2+}$ concentrations vs. $\mathrm{pH}_{\text {in situ }}$ and Eh were shown Figure 4.
Concentrations of these reduced metals were at their highest at Eh and $\mathrm{pH}_{\text {in situ }}$ below $0 \mathrm{mV}$ and 6.8, respectively, and were lower than QL at a redox below $-100 \mathrm{mV}$ (Figures 4A,B,D). The ratio $\mathrm{Fe}^{2+} / \mathrm{Mn}^{2+}$ ranged from 0.0 to 42.1 and was used to distinguish the factor affecting the behavior of these metals in relation to each other. It was significantly lower in pond $\mathrm{W}$ (mean $2.3 \pm 5.1$ ) than in pond A (mean $11.9 \pm 16.7$ ) and $\mathrm{E}$ (mean $9.3 \pm 6.6$ ) (Figure 4C). This ratio was higher in suboxic environment $(\mathrm{Eh}>-75)$ in a $\mathrm{pH}_{\text {in situ }}$ range between 6.4 and 6.7. Correlations were significant and negative between $\mathrm{pH}_{\text {in situ }}$ and $\mathrm{Fe}^{2+}(r=-0.84), \mathrm{Co}^{2+}(r=-0.79)$ and $\mathrm{Mn}^{2+}$ $(r=-0.44)$ (Supplementary Table 1). $\mathrm{Fe}^{2+}(r=0.66)$ and $\mathrm{Co}^{2+}(r=0.62)$ were significantly and positively correlated with Eh. Strong correlations were found between the ratio $\mathrm{Fe}^{2+} / \mathrm{SRP}$ $(N=15)$ and $\mathrm{pH}_{\text {in situ }}(r=-0.78)$, Eh $(r=0.70), \mathrm{Co}^{2+}(r=0.96)$ and $\mathrm{Mn}^{2+}(r=0.73)$ (Supplementary Table 1). This ratio was also significantly correlated with total $\mathrm{Mn}(r=0.55)$. 

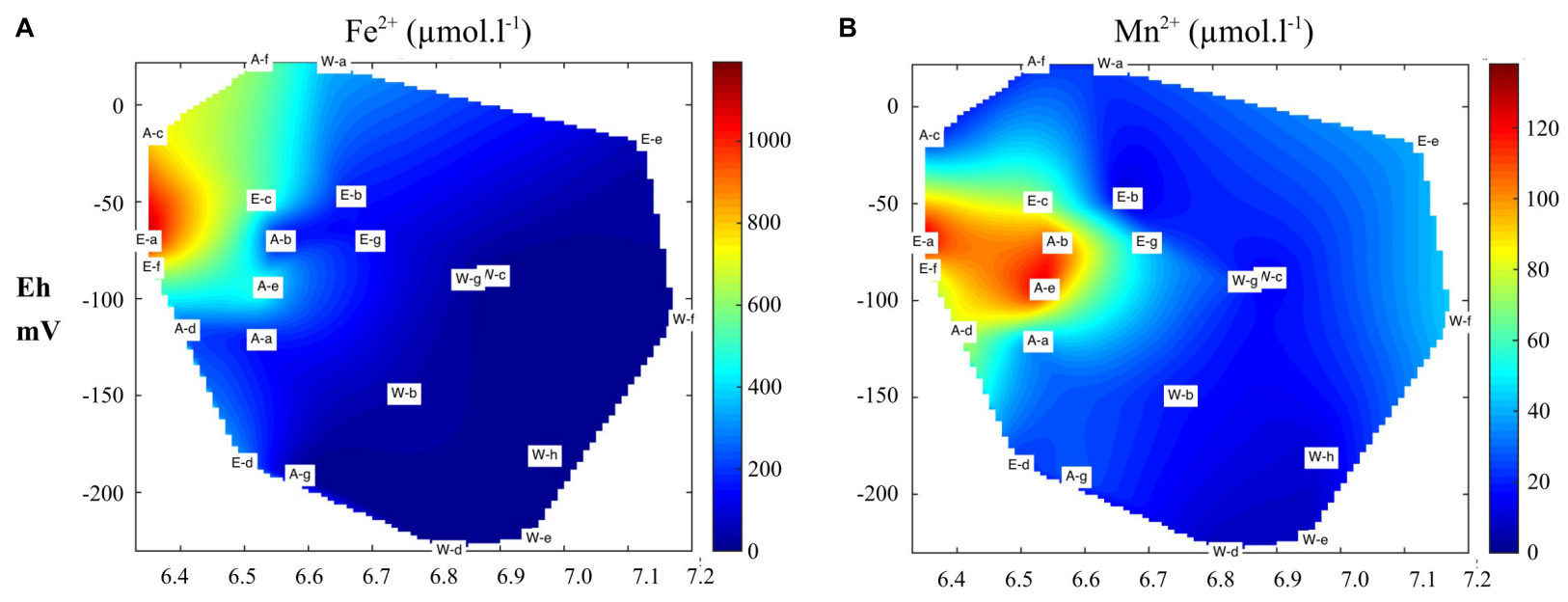

C
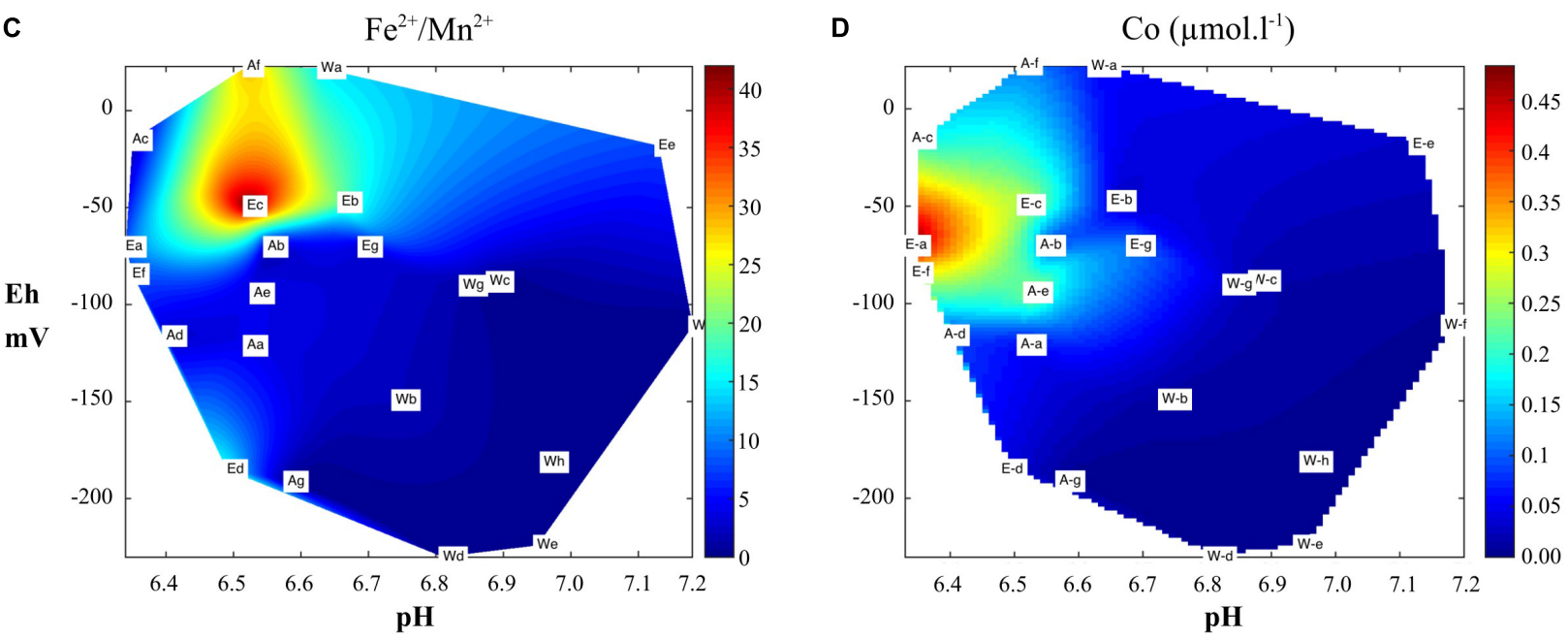

FIGURE 4 | Redox distribution (Eh) of (A) $\mathrm{Fe}^{2+}$, (B) $\mathrm{Mn}^{2+}$, (D) $\mathrm{Co}^{2+}$ concentrations, and (C) $\mathrm{Fe}^{2+} / \mathrm{Mn}^{2+}$ ratio in relation to the pH as observed in the three ponds in the first $\mathrm{cm}$ of sediment.

\section{Acid Volatile Sulfide and Chromium Reducible Sulfur}

The concentrations of $\mathrm{FeS}$ (AVS) and $\mathrm{FeS}_{2}$ (CRS) fractions ranged from QL and $289 \mu \mathrm{mol} \mathrm{g}^{-1}$ and from 7.9 and $458 \mu \mathrm{mol} \mathrm{g}^{-1}$, respectively. Two high values in horizon $\mathrm{P}$ for both parameters were explained by contamination with sediment from horizon $\mathrm{M}$ during sampling.

Figure 5A shows the profile of averaged concentration of FeS $(n=3)$ for each pond. Significant differences occurred between horizons with the highest values observed in horizon S, showing formation and accumulation of FeS during rearing.

As observed for $\mathrm{FeS}$, lower mean $\mathrm{FeS}_{2}$ concentrations occurred in the deep horizon $\mathrm{P}$ (Figure 5B). The two-way ANOVA showed a significant horizon effect and no pond effect on mean values for $\mathrm{FeS}_{2}$ (Table 2). These solid phase profiles demonstrated the formation and accumulation of $\mathrm{FeS}_{2}$ in surface sediments during rearing. In horizon $\mathrm{S}$, where highest concentrations were generally found,
$\mathrm{FeS}_{2}$ was negatively correlated with SRP measured in pore water $(r=0.89)$.

\section{DISCUSSION}

$\mathrm{Fe}^{2+}$ was more abundant at some stations of the ponds sampled in the present study (Figure 4A) than concentrations reported in other extensive shrimp farms $\left(<50 \mu \mathrm{mol} \mathrm{l^{-1 }}\right)$ (Alongi et al., 1999), natural estuarine sediments (up to $600 \mu \mathrm{mol}$ $1^{-1}$; Raimonet et al., 2013), estuaries affected by oyster culture (up to $540 \mu \mathrm{mol}^{-1}$ in superficial sediment), and even in the vicinity of Rimicaris exoculata swarms near hydrothermal vent fields (Zbinden et al., 2004). This water-sediment interface was the shrimp's living environment described as an area that can cause stress to the animals (Lemonnier et al., 2004a; Mugnier et al., 2006). Animals were therefore in contact with these environmental conditions and the link between these concentrations and accumulation in the $O G$ for aquatic 
A

AVS

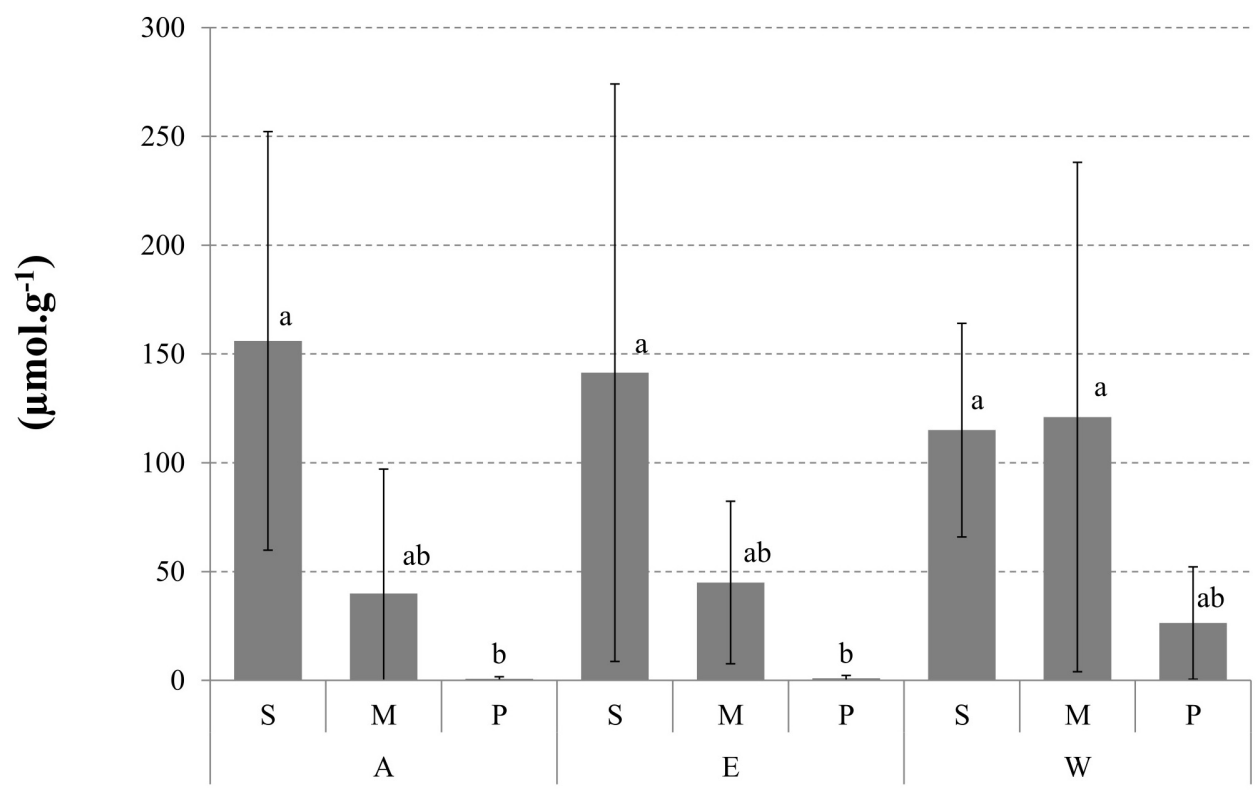

B

\section{CRS}

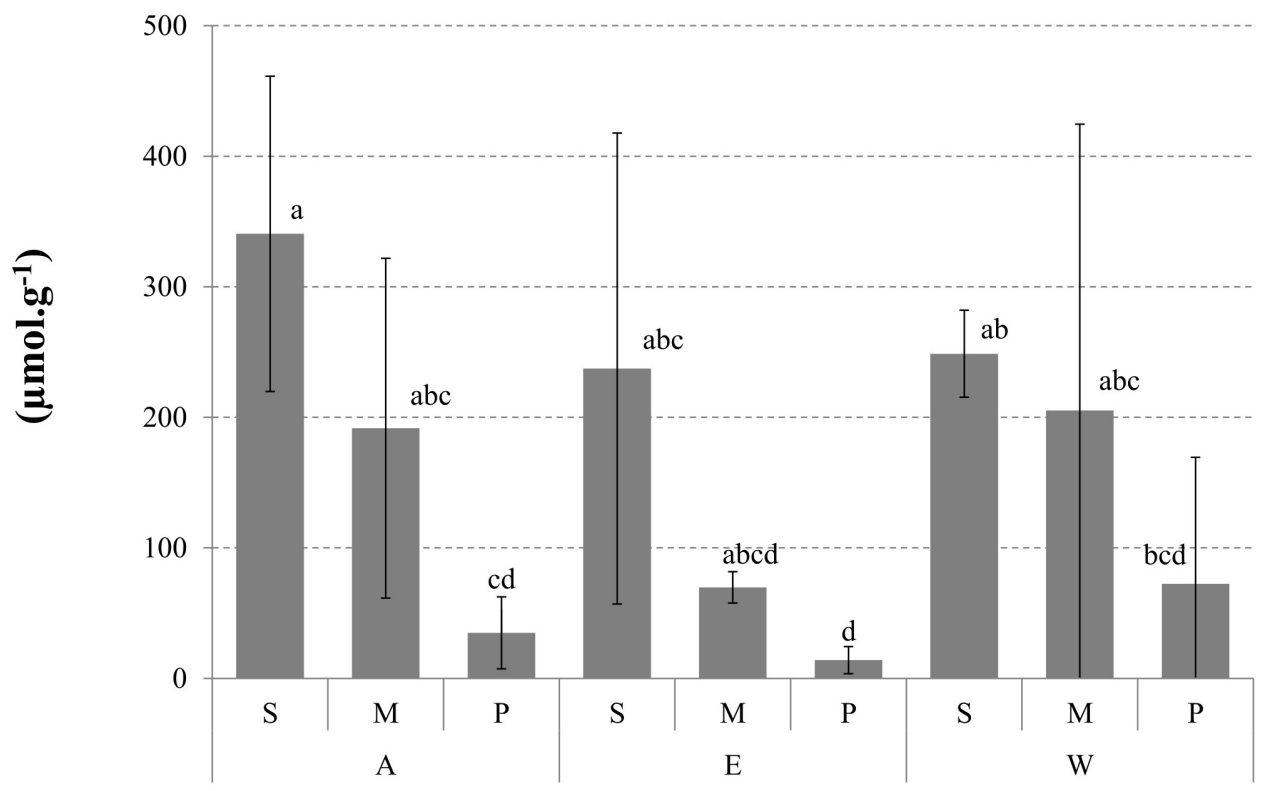

FIGURE 5 | Depth profiles of (A) acid volatile sulfides (AVS) and (B) chromium reducible sulfur (CRS) given in $\mu \mathrm{mol} \mathrm{g}^{-1} \mathrm{dw}$. AVS and CRS are the average of three cores $( \pm \mathrm{SD})$. Lower case letters show the groups of ponds differentiated by the Dunn's multiple comparison test following a significant non-parametric Kruskal-Wallis test.

organisms has already been shown experimentally for much lower concentrations (FeIII $=0.5 \mathrm{mg} \mathrm{l}^{-1}$ ) (Teien et al., 2008). However, the processes that lead to high $\mathrm{Fe}^{2+}$ concentrations was poorly described for tropical earthen ponds.
In many deposits, a well-developed sequence of electron acceptors [following the order: $\mathrm{O}_{2}, \mathrm{NO}_{3}{ }^{-}, \mathrm{Mn}(\mathrm{IV}), \mathrm{Fe}(\mathrm{III})$, and $\mathrm{SO}_{4}{ }^{2-}$ ] is involved in the oxidation of sedimentary organic matter by microorganisms. In anoxic and organic-rich habitats 
such as aquaculture systems, accumulated organic matter can react with $\mathrm{SO}_{4}{ }^{2-}$, present at high concentrations in seawater, to produce $\mathrm{H}_{2} \mathrm{~S}$ (Holmer and Kristensen, 1992; Hansen et al., 1993). Equation 1 (Table 4) represents this process, where OM is represented by the generalized formula for carbohydrate, $\mathrm{CH}_{2} \mathrm{O}$ (Rickard and Luther, 2007). High $\mathrm{H}_{2} \mathrm{~S}$ concentrations (up to $736 \mu \mathrm{mol} \mathrm{l}^{-1}$ ) were measured in pore water in the present study. Sulfate is taken up as a nutrient and reduced to sulfide by the ubiquitous sulfate-reducing bacteria (SRB), which are the main actors in anaerobic carbon cycling in marine sediment (Muyzer and Stams, 2008). These bacteria are almost entirely mesophilic, with maximum growth occurring in the $\mathrm{pH}$ range of 6-8 (White et al., 1997) in accordance with the conditions found during this study. In the present study, the highest $\mathrm{H}_{2} \mathrm{~S}$ concentrations could indicate stressful conditions and occurred in anoxic environment characterized by $\mathrm{Eh}<-125 \mathrm{mV}$ and $\mathrm{pH}>6.8$ (Li et al., 2017). However, most of the $\mathrm{H}_{2} \mathrm{~S}$ concentrations were weak and lower than $10 \mu \mathrm{mol} \mathrm{l}^{-1}$ (Figure 3F). Several mechanisms may account for these low values despite high concentrations of organic matter measured in sediment. $\mathrm{H}_{2} \mathrm{~S}$ produced could be converted effectively to $\mathrm{SO}_{4}{ }^{2-}$ by sulfur oxidizing bacteria (SOB). This process was shown to represent 2 and $84 \%$ of sediment oxygen demand (SOD) at the beginning and end of the growth period, respectively (Suplee and Cotner, 1996). Sulfide reoxidation could therefore be promoted by aerators that oxygenate the ponds, such as the trade wind and shrimp through bioturbation. Bioturbation, which is a major process in shrimp ponds (Hochard et al., 2019), is shown to favor the influx of oxygen-rich water deeper into the sediment and the rapid transport of sediment particles between oxic and anoxic conditions (Thamdrup et al., 1994). Low measured concentrations of $\mathrm{H}_{2} \mathrm{~S}$ could also be explained by the presence of amorphous Fe(III)-oxyhydroxide and Fe(III), which inhibits sulfate reduction by out-competing sulfate reducers for electron donors (Lovley and Phillips, 1987). In anoxic and slightly acidic conditions $(\mathrm{pH}<6.7)$, most of the reduced forms of sulfur $\left(\mathrm{H}_{2} \mathrm{~S}\right)$ produced had first to precipitate with $\mathrm{Fe}^{2+}$

TABLE 4 | Main reactions identified in diagenetic processes in shrimp ponds.

\begin{tabular}{|c|c|}
\hline $\begin{array}{l}\text { Reference } \\
\text { number }\end{array}$ & Equations \\
\hline 1 & $2 \mathrm{CH}_{2} \mathrm{O}_{(\mathrm{s})}+\mathrm{SO}_{4}{ }^{2-}{ }_{(a q)} \rightarrow \mathrm{H}_{2} \mathrm{~S}(\mathrm{~g})+2 \mathrm{HCO}_{3}{ }^{-}{ }_{(a q)}$ \\
\hline 2 & $\mathrm{Fe}^{2+}+\mathrm{HS}^{-} \rightarrow \mathrm{FeS}+\mathrm{H}^{+}$ \\
\hline 3 & $\mathrm{Fe}^{2+}+\mathrm{H}_{2} \mathrm{~S} \rightarrow \mathrm{FeS}+2 \mathrm{H}^{+}$ \\
\hline 4 & $4 \mathrm{FeOOH}+\mathrm{CH}_{2} \mathrm{O}+7 \mathrm{H}^{+} \rightarrow 4 \mathrm{Fe}^{2+}+\mathrm{HCO}_{3}^{-}+6 \mathrm{H}_{2} \mathrm{O}$ \\
\hline 5 & $2 \mathrm{MnO}_{2}+\mathrm{CH}_{2} \mathrm{O}+3 \mathrm{H}^{+} \rightarrow 2 \mathrm{Mn}^{2+}+\mathrm{HCO}_{3}^{-}+2 \mathrm{H}_{2} \mathrm{O}$ \\
\hline 6 & $\left(\mathrm{CH}_{2} \mathrm{O}\right) \mathrm{x}+4 \mathrm{MnO}_{2} \rightarrow 4 \mathrm{Mn}^{3+}-\mathrm{L}+\mathrm{CO}_{2}+\mathrm{H}_{2} \mathrm{O}$ \\
\hline 7 & $2 \mathrm{Fe}^{2+}+\mathrm{MnO}_{2}+2 \mathrm{H}_{2} \mathrm{O} \rightarrow \mathrm{Mn}^{2+}+2 \mathrm{FeOOH}+2 \mathrm{H}^{+}$ \\
\hline 8 & $3 \mathrm{H}^{+}+\mathrm{MnO}_{2}+\mathrm{HS}^{-} \rightarrow \mathrm{Mn}^{2+}+\mathrm{S}^{0}+2 \mathrm{H}_{2} \mathrm{O}$ \\
\hline 9 & $4 \mathrm{H}^{+}+3 \mathrm{MnO}_{2}+\mathrm{S}^{0} \rightarrow 3 \mathrm{Mn}^{2+}+\mathrm{SO}_{4}^{2-}+2 \mathrm{H}_{2} \mathrm{O}$ \\
\hline 10 & $8 \mathrm{H}^{+}+4 \mathrm{MnO}_{2}+\mathrm{FES} \rightarrow 4 \mathrm{Mn}^{2+}+\mathrm{SO}_{4}^{2-}+\mathrm{Fe}^{2+}+4 \mathrm{H}_{2} \mathrm{C}$ \\
\hline 11 & $\mathrm{FeS}+\mathrm{H}_{2} \mathrm{~S} \rightarrow \mathrm{FeS}_{2(s)}+\mathrm{H}_{2(g)}\left(\mathrm{H}_{2} \mathrm{~S}\right.$ pathway $)$ \\
\hline 12 & $\mathrm{FeS}+\mathrm{S}_{x}{ }^{2-} \rightarrow \mathrm{FeS}_{2(s)}+\mathrm{S}_{x-1}{ }^{2-}$ (Polysulfide pathway) \\
\hline 13 & $2 \mathrm{Fe}(\mathrm{OH})_{3}+\mathrm{HS}^{-}+5 \mathrm{H}^{+} \rightarrow 2 \mathrm{Fe}^{2+}+\mathrm{S}^{0}+6 \mathrm{H}_{2} \mathrm{O}$ \\
\hline 14 & $\mathrm{FeS}_{2}+7 / 2 \mathrm{O}_{2}+\mathrm{H} 2 \mathrm{O} \rightarrow \mathrm{Fe}^{2+}+2 \mathrm{H}^{+}+2 \mathrm{SO}_{4}^{2-}$ \\
\hline 15 & $\mathrm{Fe}^{2+}+\mathrm{H}^{+}+1 / 4 \mathrm{O}_{2} \rightarrow \mathrm{Fe}^{3+}+1 / 2 \mathrm{H}_{2} \mathrm{O}$ \\
\hline
\end{tabular}

as iron sulfides (FeS) (Rickard and Morse, 2005) (Equations 2 and 3; Table 4).

Within redox higher than $-125 \mathrm{mV}$, iron oxide reduction could be a major process for mineralizing organic matter and outcompeting $\mathrm{SO}_{4}{ }^{2-}$ reduction (Lovley and Phillips, 1987). In the present study, high concentrations of $\mathrm{Fe}^{2+}$ measured in pore water support this view (Canfield et al., 1993; Equation 4, Table 4). In the coastal environment of New Caledonia, $\mathrm{Fe}$ is present in high proportions in sediment mainly as goethite, one of the most reactive forms of $\mathrm{Fe}$, and as hematite $\left(\mathrm{Fe}_{2} \mathrm{O}_{3}\right)$ (Ambatsian et al., 1997). The iron provided by food with a content of $0.87 \mu \mathrm{g} \mathrm{g}^{-1}$ (DW) could also be another potential source of this metal. Significant $\mathrm{Fe}^{2+}$ concentrations were observed in ponds for specific physico-chemical conditions characterized by $\mathrm{pH}<6.7$ and Eh ranging from -125 to $0 \mathrm{mV}$ (Figure 4A). These values were similar to those reported by Gomez et al. (1999) in experimental conditions. Moreover, as $\mathrm{Fe}^{2+}$ was highly correlated with $\mathrm{pH}$, this suggests that weak acid conditions maintained this compound in solution and/or the dissimilatory reduction of iron. Because $\mathrm{H}_{2} \mathrm{~S}$ formation may be limited in these environmental conditions, $\mathrm{Fe}^{2+}$ could also be produced in quantities greatly exceeding the binding capacity of this sulfur compound.

In suboxic conditions, concentrations could be controlled by precipitation as oxides and hydroxides above the redox boundary (autogenic oxides) and driven by both abiotic and biotic reactions (Fortin and Langley, 2005). The pseudo-firstorder rate constant $(\mathrm{k})$ for oxidation of $\mathrm{Fe}^{2+}$ has been studied in seawater suggesting that abiotic oxidation could be the main pathway when $\mathrm{pH}$ exceeds 6.5 (Millero et al., 1987), as observed in our field work. The dissimilatory metal reduction processes in this suboxic environment might also be limited by the weak OM content (Figure 3C). In anoxic conditions, concentrations could be controlled by reaction with sulfide (see above).

Like Fe, Mn was present at high levels in our sediments and $\mathrm{MnO}_{2}$ reduction by microbial activity could be also a significant process (Equation 5, Table 4) through which organic matter was mineralized (Canfield et al., 1993). Pore water data collection shows active localized zones of organic matter decomposition, where reduction of $\mathrm{Mn}$ oxides, $\mathrm{Fe}$ oxides and $\mathrm{SO}_{4}{ }^{2-}$ occurred simultaneously as already reported in harbor marine sediments (Naylor et al., 2004). However, high dissolved $\mathrm{Fe}^{2+}$ contents appeared in pore water in the ponds at higher Eh and lower $\mathrm{pH}$ values than $\mathrm{Mn}^{2+}$, and several studies have reported that $\mathrm{Mn}$ precedes $\mathrm{Fe}$ reduction in the oxidation of organic carbon (Canfield et al., 1993). It was possible that some of the reduced Fe and reduced Mn were taken up by microphytobenthos, limiting the stock of these metals in pore water (Powell and Martens, 2005). However, the effect of Mn and Fe as regulating factors for the microphytobenthos compartment have been poorly explored, particularly in turbid environments such as aquaculture ponds. We hypothesis that under no nutrient limitation as found in rich sediment, Fe and Mn could favor the growth and development of microphytobenthos, as suggested by the proximity of high chl $a$ biomass and high $\mathrm{Fe}^{2+}$ and $\mathrm{Mn}^{2+}$ concentrations measured in sub-oxic and slightly acidic conditions (Figures 3A, 4A,B). Oxygen production by microphytobenthos might also result in 
Fe and $\mathrm{Mn}$ oxidation. High values of $\mathrm{Fe}^{2+} / \mathrm{Mn}^{2+}$ coincided with specific environmental conditions characterized by suboxic conditions $(\sim-50 \mathrm{mV})$ and a $\mathrm{pH}$ range between 6.4 and 6.7 (Figure 4C). This finding may partially be explained by the fact that, compared to $\mathrm{Fe}^{2+}, \mathrm{Mn}^{2+}$ is stable over a wide range of $\mathrm{Eh} / \mathrm{pH}$ conditions (Otero et al., 2006), which should always lead to precipitation of Fe before Mn (Krauskopf, 1957). Consequently, stations with the lowest $\mathrm{Fe}^{2+}$ concentrations $\left(<1.6 \mu \mathrm{mol} \mathrm{l^{-1 }}\right)$ showed significant concentrations of $\mathrm{Mn}^{2+}$ ranging from 6.2 and $45 \mu \mathrm{mol} \mathrm{l}^{-1}$. Madison et al. (2013) showed that soluble $\mathrm{Mn}$ (III) complexes, which can be produced from $\mathrm{MnO}_{2}$ and reduced by microbial activity to $\mathrm{Mn}^{2+}$, are maximum near the oxic-suboxic surface below the zone enriched in Mnoxides (Equation 6, Table 4). In aquaculture ponds, this reduction process could be involved in $\mathrm{MnO}_{2}$ reduction processes and greatly enhanced by shrimp bioturbation. $\mathrm{MnO}_{2}$ can be reduced to $\mathrm{Mn}^{2+}$ through abiotic reduction with $\mathrm{Fe}^{2+}$ (Equation 7), $\mathrm{HS}^{-}$ (Equation 8), $\mathrm{S}^{0}$ (Equation 9) or FeS (Equation 10) (Table 4; Aller and Rude, 1988; Madison et al., 2013).

In suboxic conditions and $\mathrm{pH}>6.7, \mathrm{Fe}^{2+}$ could be readily oxidized by $\mathrm{Mn}$-oxides liberating dissolved $\mathrm{Mn}^{2+}$ into pore water (Equation 7, Table 4; Van Cappellen and Wang, 1996). Burdige et al. (1992) showed that this process occurs faster than by microbial Mn reduction but is strongly dependent on the particular oxide being reduced. In anoxic conditions $(<100 \mathrm{mV})$, the reduction of $\mathrm{Mn}$-oxides by $\mathrm{SO}_{4}{ }^{2-}$ was also involved to a large extent in the formation of reduced dissolved Mn (Aller and Rude, 1988). The source of sulfur was probably FeS. In sulfidic and anoxic conditions, $\mathrm{Mn}$ (II) could be removed by coprecipitation with FeS (Huerta-Diaz et al., 1998). However, Mn(II) does not easily form a MnS phase and is incorporated into pyrite at high degrees of pyritization of Fe (Morse and Luther, 1999).

Co was released in pore waters within the zone of $\mathrm{Mn}$ and Fe reductions. Heggie and Lewis (1984) have reported that Co is released in pore waters in sub-oxic conditions and it is instructive to note the profile of Co has been shown to be closely correlated with those of $\mathrm{Mn}^{2+}$ and $\mathrm{Fe}^{2+}$. The high correlation between $\mathrm{Co}^{2+}$ and $\mathrm{Fe}^{2+}(r=0.94)$ can be attributed to the similarity of their reactions to environmental changes (Stockdale et al., 2010). During early diagenesis, Co could be released by reductive dissolution of $\mathrm{Fe}$ (III) [oxy(hydroxides)] and $\mathrm{Mn}$ (III, IV) oxides (Taillefert et al., 2002). The formation of authigenic phases has been described as subject to thermodynamic control based on Eh and $\mathrm{pH}$ conditions and $\mathrm{Co}^{2+}$ concentrations (Swanner et al., 2014). Adsorption of $\mathrm{Co}^{2+}$ to ferrihydrite was assumed to be the dominant Co scavenging pathway as described for $\mathrm{Fe}^{2+}$-rich seawater. However, Co could also be potentially fixed by some organic-ligands limiting its sorption by ferrihydrite in extreme cases (Swanner et al., 2014).

In anoxic conditions, the formation of sulfide may impact the concentrations of $\mathrm{Co}^{2+}$. Because $\mathrm{FeS}$ is more soluble than $\mathrm{CoS}$, Co may first be incorporated into FeS before precipitating as $\mathrm{CoS}$ (Morse and Luther, 1999). $\mathrm{Co}^{2+}$ was less correlated with $\mathrm{Mn}(r=0.68)$ than with $\mathrm{Fe}$, which may be due to the reactivity difference of these two metals with sulfide (Saito et al., 2003). Cobalt, as the central metal cofactor in vitamin $\mathrm{B} 12$, is an essential micronutrient for phytoplankton growth and can substitute for $\mathrm{Zn}$ in carbonic anhydrase involved in photosynthesis processes (Morel et al., 1994). As reported for $\mathrm{Mn}$ and $\mathrm{Fe}$, Co concentrations could be controlled by microphytobenthos uptake in no nutrient limitation conditions and/or binding by organic ligands (Saito and Moffett, 2001) rather than by scavenging reactions with $\mathrm{Fe}$ and $\mathrm{Mn}$. This uptake may explain the low Co concentrations, when high chl $a$ concentrations was observed (Figures 3A, 4D).

Pyrite formation from FeS proceeds through two chemical pathways (Rickard, 1997), both of which were potentially present in our study. The $\mathrm{H}_{2} \mathrm{~S}$ pathway (Equation 11, Table 4) is more important in low $\mathrm{pH}$ environments, due to $\mathrm{pH}$-dependent speciation of reduced sulfide. It tends to be favored in strictly anoxic environments and the reaction is surprisingly fast at ambient temperatures (50\% within 1 day) (Rickard, 1997). The polysulfide pathway (Equation 12, Table 4) can be the dominant pyrite formation process with neutral $\mathrm{pH}$ values (Yücel et al., 2010). In the anoxic zone $(\mathrm{Eh}<-125 \mathrm{mV})$ when pore water sulfide was available, FeOOH could be directly reduced (Rickard, 1975) (Equation 13, Table 4). In slightly acidic conditions, the production of $\mathrm{Fe}_{2}{ }^{+}$could keep dissolution of sulfide at low levels due to its diagenetic conversion to pyrite (Figure 3D). Pyrite formation from $\mathrm{FeS}$ and $\mathrm{H}_{2} \mathrm{~S}$ could also be mediated at ambient temperature through a microbially catalyzed redox process (Thiel et al., 2019).

In our study, the formation of $\mathrm{FeS}$ and $\mathrm{FeS}_{2}$ reached a maximum in horizon $S$ in these slightly acidic conditions (stations $\mathrm{Ab}, \mathrm{Ed}$, and $\mathrm{Wd}$ ), with concentrations $>230$ and $>370 \mu \mathrm{mol} \mathrm{g}^{-1}(\mathrm{dw})$, respectively (Figure 5). However, the lack of data does not allow us to define the environmental conditions associated with the production of these compounds in a pond environment. Sulfur species were not found or were found only at low concentration in horizon $\mathrm{P}$, indicating that original soil where ponds has been built could not be classified as an acidic sulfate soil. These initial $\mathrm{FeS}$ and $\mathrm{FeS}_{2}$ levels could not explain the high values found in the $S$ and $M$ horizons in all samples, including those collected in oxic and suboxic conditions. This finding suggests that sulfidization occurred in all of them and/or from a previous increase in sulfide flux from horizons $M$ to S (Yücel et al., 2010). Fe sulfidization has previously been reported in surface sediments under eutrophic marine conditions without requiring oxygen depletion in the overlying waters (Kraal et al., 2013). Several authors have revealed the occurrence of $\mathrm{SO}_{4}{ }^{2-}$ reduction and anaerobic processes in micro-niches in oxic and suboxic environments (Jørgensen and Bak, 1991). In our study, the positive correlation between TOC and $\mathrm{FeS}_{2}$ (Pearson's correlation, $p<0.01 ; F=19.36$ ) in horizon $M$ suggests that the formation of pyrite was mainly dependent of the sulfide produced through the activity of the sulfate reducer (Yücel et al., 2010). The absence of correlation in horizon $S(P>0.05)$ can be firstly attributed to $\mathrm{FeS}_{2}$ transfer by bioturbation to the sediment surface where it could be oxidized by oxygen (Thamdrup et al., 1994). The absence of correlation could also be due to the presence of "old" pyrite accumulated during former crops (Munsiri et al., 1996). The occurrence of high FeS concentrations in marine sediments as observed in our study is generally uncommon (Gagnon et al., 1995). Such 
FeS enrichments could be attributed firstly to the high level of SRB activity in ponds for mineralizing accumulated organic matter (Suplee and Cotner, 1996). However, this enrichment could also been attributed to the retardation of pyrite formation through depletion of $\mathrm{H}_{2} \mathrm{~S}$ by rapid FeS formation in Fe-rich systems (Gagnon et al., 1995; Burton et al., 2011) - the reaction between $\mathrm{FeS}$ and $\mathrm{H}_{2} \mathrm{~S}$ being slow in an anoxic environment and to the competition for reactants by organic compounds (Benning et al., 2000). The mean values of the ratio between FeS and $\mathrm{FeS}_{2}$ in horizons $\mathrm{S}$ and $\mathrm{M}(0.48 \pm 0.20$ and $0.53 \pm 0.52$, respectively), which was relatively high compared to the values reported in different ecosystems (Gagnon et al., 1995), indicated a low efficiency conversion of FeS to pyrite. After the shrimp harvest, ponds were exposed to air to improve pond bottom conditions. This practice leads to the oxidization of pyrite and generate a concomitant acidic media and releases of significant amounts of sulfates and soluble metal cations (Equations 14 and 15, Table 4; Karimian et al., 2018), as already reported in New Caledonia in salt marsh isolated from the sea (Noël et al., 2017) or in the upper sediments beneath Avicennia and Rhizophora stands (Noël et al., 2014). This process has been found to occur when the buffering capacity of the sediment becomes lower than the capacity of sulfuric acid production.

This process is assumed to induce a concomitant and progressive soil acidification with successive crops. After 30 years of activity, the buffering capacity of sediment is perhaps exhausted. A diagnostic survey should be carried out to analyze the pyrite acidity in sediment using the hydrogen peroxide method to validate this hypothesis (Boyd and Tucker, 1998). Specific liming rates should be calculated to neutralize exchangeable acidity and potential acidity from pyrite oxidation, taking into account that liming materials will not react the same way in acid-sulfate soil as they do in non-acid-sulfate soils (Boyd et al., 2016). Our knowledge on chemical characteristics of pore waters in shrimp ponds should also be improved to better determine the $\mathrm{pH}_{\text {in situ }}$ changes during rearing to develop appropriate management option for avoiding acidification of the sediment. The $\mathrm{pH}$ measured in situ may vary during a 24$h$ period because of changes in carbon cycling in response to differences in rates of photosynthesis and respiration of the microphytobenthos. The $\mathrm{CO}_{2}$ produced by the microbiological metabolism of accumulated organic matter affects also the $\mathrm{pH}$. Other processes involving the consumption of $\mathrm{H}^{+}$ions such as denitrification, sulfate reduction and reductions of FeIII and Mn IV counter balance the decrease of $\mathrm{pH}$ in anoxic sediment (Berner et al., 1970). Total alkalinity (TA) should be analyzed in the future to determine the neutralizing capacity of pore water in this system.

To conclude, this study shows the accumulation of reduced Fe, $\mathrm{Co}$ and $\mathrm{Mn}$ in suboxic and slightly acidic sediment. In a previous study, histological, biochemical and electronic microscopy on gills sampled in the same farm have shown an accumulation of iron and aluminum at the surface of the gills, and cobalt in the whole tissue (Wabete et al., 2015). Acidic conditions measured in ponds explained the release of metal ions, particularly Fe and $\mathrm{Al}$ and their deposits as oxide forms at the surface of the gills. In sulfate soils, $\mathrm{Al}$ is mobilized from soils, and its exposure known to induce structural abnormalities in the gills for penaeid shrimp (Russell et al., 2019). Because Co did not show any accumulation at the surface of the gill, it is possible that Co was transported from the exoskeleton to this tissue. Manganese measured at very high concentration in pore water in the present study did not show any or little accumulation in the gills. The triggering factor of gills coloration might be the heterotrophic shift of the system linked to OM accumulation at the sediment interface during shrimp culture. We hypothesis that the formation of pyrite couple with pond age might induce a decrease in the buffering capacity of the sediment which result in sediment acidification during rearing. Two factors were implied to explain the occurrence of OG during shrimp culture: (1) the proportion of shrimp in premolt stage and (2) the iron concentration at the sediment interface (depending on $\mathrm{pH}_{\text {in situ }}$ and redox). The evolution of these factors could explain the variations of orange gill percentage in the shrimp population during rearing.

\section{DATA AVAILABILITY STATEMENT}

The datasets presented in this study can be found in online repositories. The names of the repository/repositories and accession number(s) can be found below: https:/doi.org/10. 17882/76793.

\section{AUTHOR CONTRIBUTIONS}

HL: conceptualization, writing, and investigation. FR: investigation and resources. FC, $\mathrm{CH}$, and ÉR: investigation. EL: investigation and visualization. TD: visualization. J-MF: reviewing. FA-L: writing and reviewing. All authors contributed to the article and approved the submitted version.

\section{FUNDING}

This work was supported by a research grant jointly provided by Northern Province, Southern Province, the Government of New Caledonia and Institut Français de Recherche et d'Exploitation de la Mer (IFREMER) (No. 12/1219969/C).

\section{ACKNOWLEDGMENTS}

The authors thank the reviewers for their useful comments and suggestions, which improved the manuscript. We would also like to thank the staff of LAMA (Laboratoire des Moyens Analytiques de l'IRD de Nouméa) for their technical assistance. We also thank the farmer who kindly helped us in this study.

\section{SUPPLEMENTARY MATERIAL}

The Supplementary Material for this article can be found online at: https://www.frontiersin.org/articles/10.3389/fmars.2021. 625789/full\#supplementary-material 


\section{REFERENCES}

Aller, R. C., and Rude, P. D. (1988). Complete oxidation of solid phase sulfides by manganese and bacteria in anoxic marine sediments. Geochim. Cosmochim. Acta 52, 751-765. doi: 10.1016/0016-7037(88)90335-3

Alongi, D. M., Tirendi, F., and Trott, L. A. (1999). Rates and pathways of benthic mineralization in extensive shrimp ponds of the Mekong delta, Vietnam. Aquaculture 175, 269-292. doi: 10.1016/s0044-8486(99)00077-0

Ambatsian, P., Fernex, F., Bernat, M., Parron, C., and Lecolle, J. (1997). High metal inputs to closed seas: the New Caledonian lagoon. J. Geochem. Expl. 59, 59-74. doi: 10.1016/s0375-6742(96)00020-9

Avnimelech, Y., and Ritvo, G. (2003). Shrimp and fish pond soils: processes and management. Aquaculture 220, 549-567. doi: 10.1016/s0044-8486(02)00641-5

Benning, L. G., Wilkin, R. T., and Barnes, H. L. (2000). Reaction pathways in the Fe-S system below $100^{\circ}$ C. Chem. Geol. 167, 25-51. doi: 10.1016/s0009-2541(99) 00198-9

Berner, R. A., Scott, M. R., and Catherine Thomlinson, C. (1970). Carbonate alkalinity in the pore water of anoxic marine sediments. Limnol. Oceanogr. 15, 544-549. doi: 10.4319/lo.1970.15.4.0544

Boyd, C. E. (1995). in Bottom Soils, Sediment, and Pond Aquaculture, eds Chapman and Hall (New York, NY: Springer US), 348.

Boyd, C. E., and Tucker, C. S. (1998). Pond Aquaculture Water Quality Management. Boston MA: Kluwer Academic Publisher.

Boyd, C. E., Tucker, C. S., and Somridhivej, B. (2016). Alkalinity and hardness: critical but elusive concepts in aquaculture. J. World Aquac. Soc. 47, 6-41. doi: 10.1111 /jwas. 12241

Briand, M. J., Letourneur, Y., Bonnet, X., Wafo, E., Fauvel, T., Brischoux, F., et al. (2014). Spatial variability of metallic and organic contamination of anguilliform fish in New Caledonia. Environ. Sci. Pollut. Res. 21, 4576-4591. doi: 10.1007/ s11356-013-2327-0

Burdige, D. J., Dhakar, S. P., and Nealson, K. H. (1992). Effects of manganese oxide mineralogy on microbial and chemical manganese reduction. Geomicrobiol. J. 10, 27-48. doi: 10.1080/01490459209377902

Burford, M. A., Costanzo, S. D., Dennison, W. C., Jackson, C. J., Jones, A. B., McKinnon, A. D., et al. (2003). A synthesis of dominant ecological processes in intensive shrimp ponds and adjacent coastal environments in NE Australia. Mar. Pollut. Bull. 46, 1456-1469. doi: 10.1016/s0025-326x(03)00282-0

Burton, E. D., Bush, R. T., Johnston, S. G., Sullivan, L. A., and Keene, A. F. (2011). Sulfur biogeochemical cycling and novel Fe-S mineralization pathways in a tidally re-flooded wetland. Geochim. Cosmochim. Acta 75, 3434-3451. doi: 10.1016/j.gca.2011.03.020

Canfield, D. E., Raiswell, R., Westrich, J. T., Reaves, C. M., and Berner, R. A. (1986) The use of chromium reduction in the analysis of reduced inorganic sulfur in sediments and shales. Chem. Geol. 54, 149-155. doi: 10.1016/0009-2541(86) 90078- 1

Canfield, D. E., Thamdrup, B., and Hansen, J. W. (1993). The anaerobic degradation of organic matter in Danish coastal sediments: iron reduction, manganese reduction, and sulfate reduction. Geochim. Cosmochim. Acta 57, 3867-3883. doi: 10.1016/0016-7037(93)90340-3

Fonselius, S., Dyrssen, D., and Yhlen, B. (2007). "Determination of hydrogen sulphide," in Methods of Seawater Analysis, eds K. Grasshoff, K. Kremling, and M. Ehrhardt (Hoboken, NJ: Wiley).

Fortin, D., and Langley, S. (2005). Formation and occurrence of biogenic iron-rich minerals. Earth Sci. Rev. 72, 1-19. doi: 10.1016/j.earscirev.2005.03.002

Gagnon, C., Mucci, A., and Pelletier, E. (1995). Anomalous accumulation of acidvolatile sulphides (AVS) in a coastal marine sediment, Saguenay Fjord, Canada. Geochim. Cosmochim. Acta 59, 2663-2675. doi: 10.1016/0016-7037(95)00163-t

Gomez, E., Durillon, C., Rofes, G., and Picot, B. (1999). Phosphate adsorption and release from sediments of brackish lagoons: $\mathrm{pH}, \mathrm{O} 2$ and loading influence. Water Res 33, 2437-2447. doi: 10.1016/s0043-1354(98) 00468-0

Grenz, C., Le Borgne, R., Torréton, J.-P., and Fichez, R. (2013). “New Caledonia Lagoon: a threatened paradise under anthropogenic pressure?," in Lagoons: Habitat and Species, Human Impacts and Ecological Effects, ed. M. Mwinyihija (New York, NY: Nova Science), 31-56.

Hansen, L. S., Holmer, M., and Blackburn, T. H. (1993). Mineralization of organic nitrogen and carbon (fish food) added to anoxic sediment microcosm: role of sulfate reduction. Mar. Ecol. Prog. Ser. 102, 199-204. doi: 10.3354/meps095199
Hédouin, L., Bustamante, P., Churlaud, C., Pringault, O., Fichez, R., and Warnau, M. (2009). Trends in concentrations of selected metalloid and metals in two bivalves from the coral reefs in the SW lagoon of New Caledonia. Ecotoxicol. Environ. Saf. 72, 372-381. doi: 10.1016/j.ecoenv.2008.04.004

Heggie, D., and Lewis, T. (1984). Cobalt in pore waters of marine sediments. Nature. 311:453. doi: 10.1038/311453a0

Hochard, S., Royer, F., Hubert, M., and Lemonnier, H. (2019). Temporal variability of benthic-pelagic coupling in shallow enclosed environment: a case study with eutrophying shrimp ponds. Mar. Environ. Res. 146, 46-56. doi: 10.1016/j. marenvres.2019.03.005

Holmer, M., and Kristensen, E. (1992). Impact of marine cage farming on metabolism and sulfate reduction of underlying sediments. Mar. Ecol. Prog. Ser. 80, 191-201. doi: 10.3354/meps080191

Holm-Hansen, O., Lorenzen, C. J., Holmes, P. E., and Strickland, J. D. H. (1965) Fluorometric determination of chlorophyll ICES J. Mar. Sci. 30, 3-15. doi: 10.1093/icesjms/30.1.3

Huerta-Diaz, M. A., Tessier, A., and Carignan, R. (1998). Geochemistry of trace metals associated with reduced sulfur in freshwater sediments. Appl. Geochem. 13, 213-233. doi: 10.1016/s0883-2927(97)00060-7

Hussenot, J., and Martin, J. L. M. (1995). Assessment of the quality of pond sediment in aquaculture using simple, rapid techniques. Aquac. Int. 3, 123-133. doi: $10.1007 /$ bf00117879

Jørgensen, B. B., and Bak, F. (1991). Pathways and microbiology of thiosulfate transformations and sulfate reduction in a marine sediment (Kattegat, Denmark). Appl. Environ. Microbiol. 57, 847-856. doi: 10.1128/aem.57.3.847856.1991

Karimian, N., Johnston, S. G., and Burton, E. D. (2018). Iron and sulfur cycling in acid sulfate soil wetlands under dynamic redox conditions: a review. Chemosphere 197, 803-816. doi: 10.1016/j.chemosphere.2018.01.096

Kraal, P., Burton, E. D., Bush, R. T., and Supplement, C. (2013). Iron monosulfide accumulation and pyrite formation in eutrophic estuarine sediments. Geochim. Cosmochim. Acta 122, 75-88. doi: 10.1016/j.gca.2013.08.013

Krauskopf, K. B. (1957). Separation of manganese from iron in sedimentary processes. Geochim. Cosmochim. Acta 12, 61-84. doi: 10.1016/0016-7037(57) 90018-2

Lemonnier, H., Bernard, E., Boglio, E., Goarant, C., and Cochard, J.-C. (2004a). Influence of sediment characteristics on shrimp physiology: $\mathrm{pH}$ as principal effect. Aquaculture 240, 297-312. doi: 10.1016/j.aquaculture.2004.07.001

Lemonnier, H., Brizard, R., and Legrand, A. (2004b). "Influence des pratiques zootechniques de la crevette (Litopenaeus stylirostris) et de l'age des bassins sur la qualité des sédiments," in styli 2003. Trente ans de Crevetticulture en Nouvelle-Calédonie. Nouméa-Koné, 2-6 juin 2003, Vol. 38, (Brest: Ifremer), $180-186$.

Lemonnier, H., Hochard, S., Nakagawa, K., Courties, C., and Rodier, M. (2017). Response of phytoplankton to organic enrichment and shrimp activity in tropical aquaculture ponds: a mesocosm study. Aquat. Microb. Ecol. 80, 105122. doi: $10.3354 / \mathrm{ame} 01841$

Li, T., Li, E., Suo, Y., Xu, Z., Jia, Y., Qin, J. G., et al. (2017). Energy metabolism and metabolomics response of Pacific white shrimp Litopenaeus vannamei to sulfide toxicity. Aqua. Toxicol. 183, 28-37. doi: 10.1016/j.aquatox.2016.12.010

Lovley, D. R., and Phillips, E. J. (1987). Competitive mechanisms for inhibition of sulfate reduction and methane production in the zone of ferric iron reduction in sediments. Appl. Environ. Microbiol. 53, 2636-2641. doi: 10.1128/aem.53.11. 2636-2641.1987

Luong, C. T., Hochard, S., Royer, F., Lemonnier, H., and Letourneur, Y. (2014). Feasibility of polyculture of blue shrimp Litopenaeus stylirostris with goldlined rabbitfish Siganus lineatus in a closed culture system: a mesocosm study. Aquaculture 433, 340-347. doi: 10.1016/j.aquaculture.2014.06.014

Luong, T. C., Lemonnier, H., Hochard, S., Royer, F., and Letourneur, Y. (2016). Effects of blue shrimp Litopenaeus Stylirostris and goldlined rabbitfish Siganus Lineatus in mono- and polyculture on production and environmental conditions. Aquacult. Res. 48, 1368-1379. doi: 10.1111/are.13201

Madison, A. S., Tebo, B. M., Mucci, A., Sundby, B. R., and Luther, G. W. (2013). Abundant porewater $\mathrm{mn}$ (III) is a major component of the sedimentary redox system. Science 341, 875-878. doi: 10.1126/science.1241396

Marchand, C., Fernandez, J. M., and Moreton, B. (2016). Trace metal geochemistry in mangrove sediments and their transfer to mangrove plants (New Caledonia). Sci. Total Environ. 562, 216-227. doi: 10.1016/j.scitotenv.2016.03.206 
Martin, J. L. M., Veran, Y., Guelorget, O., and Pham, D. (1998). Shrimp rearing: stocking density, growth, impact on sediment, waste output; their relationships studied through the nitrogen budget in rearing ponds. Aquaculture 164, 135149. doi: 10.1016/s0044-8486(98)00182-3

Metian, M., Giron, E., Borne, V., Hédouin, L., Teyssié, J.-L., and Warnau, M. (2008). The brown alga Lobophora variegata, a bioindicator species for surveying metal contamination in tropical marine environments. J. Exp. Mar. Biol. Ecol. 362, 49-54. doi: 10.1016/j.jembe.2008.05.013

Millero, F. J., Sotolongo, S., and Izaguirre, M. (1987). The oxidation kinetics of $\mathrm{Fe}(\mathrm{II})$ in seawater. Geochim. Cosmochim. Acta 51, 793-801. doi: 10.1016/00167037(87)90093-7

Morel, F. M. M., Reinfelder, J. R., Roberts, S. B., Chamberlain, C. P., Lee, J. G., and Yee, D. (1994). Zinc and carbon co-limitation of marine phytoplankton. Nature 369, 740-742. doi: 10.1038/369740a0

Moreton, B. M., Fernandez, J.-M., and Dolbecq, M. B. D. (2009). Development of a field preconcentration / elution unit for routine determination of dissolved metal concentrations by ICP-OES in marine waters: application for monitoring of the New Caledonia lagoon. Geostand. Geoanal. Res. 33, 205-218. doi: 10. 1111/j.1751-908x.2009.00899.x

Morse, J. W., and Luther, G. W. (1999). Chemical influences on trace metal-sulfide interactions in anoxic sediments. Geochim. Cosmochim. Acta 63, 3373-3378. doi: 10.1016/s0016-7037(99)00258-6

Mugnier, C., Lemonnier, H., and Legrand, A. (2006). Physiological response of the blue shrimp Litopenaeus stylirostris to short-term confinement on a pond bottom. Aquaculture 253, 703-711. doi: 10.1016/j.aquaculture.2005.09.008

Munsiri, P., Boyd, C. E., and Hajek, B. F. (1995). Physical and chemical characteristics of bottom soil profiles in ponds at Auburn, Alabama, USA and a proposed system for describing pond soil horizons. J. World Aquacult. Soc. 26, 346-376. doi: 10.1111/j.1749-7345.1995.tb00831.x

Munsiri, P., Boyd, C. E., Teichert-Coddington, D. R., and Hajek, B. F. (1996). Texture and chemical composition of soils from shrimp ponds near Choluteca, Honduras. Aqua. Int. 4, 157-168. doi: 10.1007/BF00140596

Muyzer, G., and Stams, A. J. M. (2008). The ecology and biotechnology of sulphatereducing bacteria. Nat. Rev. Micro. 6, 441-454. doi: 10.1038/nrmicro1892

Naylor, C., Davison, W., Motelica-Heino, M., Van Den Berg, G. A., and Van Der Heijdt, L. M. (2004). Simultaneous release of sulfide with Fe, Mn, Ni and Zn in marine harbour sediment measured using a combined metal/sulfide DGT probe. Sci. Total Environ. 328, 275-286. doi: 10.1016/j.scitotenv.2004.02.008

Nelson, D. W., and Sommers, L. E. (1982). "Total carbon, organic carbon, and organic matter," in Method of soils analysis: Part 2, Chemical and Microbiological Properties, eds A. L. Page, R. H. Miller, and D. R. Keeney (Madison, Wi: American Society of Agronomy and Soils Science Society of America), 539-579.

Noël, V., Juillot, F., Morin, G., Marchand, C., Ona-Nguema, G., Viollier, E., et al. (2017). Oxidation of Ni-Rich mangrove sediments after isolation from the sea (Dumbea Bay, New Caledonia): $\mathrm{Fe}$ and $\mathrm{Ni}$ Behavior and environmental implications. ACS Earth Space Chem. 1, 455-464. doi: 10.1021/ acsearthspacechem.7b00005

Noël, V., Marchand, C., Juillot, F., Ona-Nguema, G., Viollier, E., Marakovic, G., et al. (2014). EXAFS analysis of iron cycling in mangrove sediments downstream a lateritized ultramafic watershed (Vavouto Bay, New Caledonia). Geochim. Cosmochim. Acta 136, 211-228. doi: 10.1016/j.gca.2014.03. 019

Otero, X. L., Ferreira, T. O., Vidal-Torrado, P., and Macías, F. (2006). Spatial variation in pore water geochemistry in a mangrove system (Pai Matos island, Cananeia-Brazil). Appl. Geochem. 21, 2171-2186. doi: 10.1016/j.apgeochem. 2006.07.012

Peuranen, S., Vuorinen, P. J., Vuorinen, M., and Hollender, A. (1994). The effects of iron, humic acids and low $\mathrm{pH}$ on the gills and physiology of Brown Trout (Salmo trutta). Ann. Zool. Fennici 31, 389-396.

Powell, B., and Martens, M. (2005). A review of acid sulfate soil impacts, actions and policies that impact on water quality in great barrier reef catchments, including a case study on remediation at East Trinity. Mar. Pollut. Bull. 51, 149-164. doi: 10.1016/j.marpolbul.2004.10.047

Queiroz, J. F., and Boyd, C. E. (1998). Evaluation of a kit for estimating organic matter concentrations in bottom soils of aquaculture ponds. J. World Aquacult. Soc. 29, 230-233. doi: 10.1111/j.1749-7345.1998.tb00981.x

Raimonet, M., Andrieux-Loyer, F., Ragueneau, O., Michaud, E., Kerouel, R., Philippon, X., et al. (2013). Strong gradient of benthic biogeochemical processes along a macrotidal temperate estuary: focus on P and Si cycles. Biogeochemistry 115, 399-417. doi: 10.1007/s10533-013-9843-3

Rickard, D. (1975). Kinetics and mechanism of pyrite formation at low temperatures. Am. J. Sci. 275, 636-652. doi: 10.2475/ajs.275.6.636

Rickard, D. (1997). Kinetics of pyrite formation by the $\mathrm{H}_{2} \mathrm{~S}$ oxidation of iron (II) monosulfide in aqueous solutions between 25 and $125^{\circ} \mathrm{C}$ : the rate equation. Geochim. Cosmochim. Acta 61, 115-134. doi: 10.1016/s0016-7037(96)00321-3

Rickard, D., and Luther, G. W. (2007). Chemistry of iron sulfides. Chem. Rev. 107, 514-562. doi: 10.1021/cr0503658

Rickard, D., and Morse, J. W. (2005). Acid volatile sulfide (AVS). Mar. Chem. 97, 141-197. doi: 10.1016/j.marchem.2005.08.004

Rozan, T. F., Taillefert, M., Trouwborst, R. E., Glazer, B. T., Ma, S., Herszage, J., et al. (2002). Iron-sulfur-phosphorus cycling in the sediments of a shallow coastal bay: implications for sediment nutrient release and benthic macroalgal blooms. Limnol. Oceanogr. 47, 1346-1354. doi: 10.4319/lo.2002.47.5.1346

Russell, A., MacFarlane, G. R., Nowak, B., Moltschaniwskyj, N. A., and Taylor, M. D. (2019). Lethal and sub-lethal effects of aluminium on a juvenile penaeid shrimp. Thalassas 35, 359-368. doi: 10.1007/s41208-019-00152-4

Saito, M. A., and Moffett, J. W. (2001). Complexation of cobalt by natural organic ligands in the Sargasso Sea as determined by a new high-sensitivity electrochemical cobalt speciation method suitable for open ocean work. Mar. Chem. 75, 49-68. doi: 10.1016/s0304-4203(01)00025-1

Saito, M. A., Sigman, D. M., and Morel Fo, M. M. (2003). The bioinorganic chemistry of the ancient ocean: the co-evolution of cyanobacterial metal requirements and biogeochemical cycles at the Archean-Proterozoic boundary? Inorganica Chim. Acta 356, 308-318. doi: 10.1016/S0020-1693(03)00442-0

Seeberg-Elverfeldt, J., Schlüter, M., Feseker, T., and Kölling, M. (2005). Rhizon sampling of porewaters near the sediment-water interface of aquatic systems. Limnol. Oceanogr. Methods 3, 361-371. doi: 10.4319/lom.2005.3.361

Stockdale, A., Davison, W., Zhang, H., and Hamilton-Taylor, J. (2010). The Association of cobalt with iron and manganese (Oxyhydr)oxides in Marine Sediment. Aqua. Geochem. 16, 575-585. doi: 10.1007/s10498-010-9092-1

Suplee, M. W., and Cotner, J. B. (1996). Temporal changes in oxygen demand and bacterial sulfate reduction in inland shrimp ponds. Aquaculture 145, 141-158. doi: 10.1016/s0044-8486(96)01339-7

Swanner, E. D., Planavsky, N. J., Lalonde, S. V., Robbins, L. J., Bekker, A., Rouxel, O. J., et al. (2014). Cobalt and marine redox evolution. Earth Planet. Sci. Lett. 390, 253-263. doi: 10.1016/j.epsl.2014.01.001

Taillefert, M., MacGregor, B. J., Gaillard, J.-F., Lienemann, C.-P., Perret, D., and Stahl, D. A. (2002). Evidence for a dynamic cycle between $\mathrm{mn}$ and co in the water column of a stratified lake. Env. Sci. Tech. 36, 468-476. doi: 10.1021/ es010915t

Teien, H.-C., Garmo, Ø, Åtland, Å, and Salbu, B. (2008). Transformation of iron species in mixing zones and accumulation on fish gills. Environ. Sci. Technol. 42, 1780-1786. doi: 10.1021/es071965m

Thamdrup, B., Fossing, H., and Jørgensen, B. B. (1994). Manganese, iron and sulfur cycling in a coastal marine sediment, Aarhus bay, Denmark. Geochim. Cosmochim. Acta 58, 5115-5129. doi: 10.1016/0016-7037(94)90298-4

Thiel, J., Byrne, J. M., Kappler, A., Schink, B., and Pester, M. (2019). Pyrite formation from $\mathrm{FeS}$ and $\mathrm{H} 2 \mathrm{~S}$ is mediated through microbial redox activity. Proc. Natl. Acad. Sci. U.S.A. 116, 6897-6902. doi: 10.1073/pnas.1814412116

Thunjai, T., Boyd, C. E., and Dube, K. (2001). Pond Soil pH measurement. J. World Aquacult. Soc. 32, 141-152.

Underwood, G. (2002). Adaptations of tropical marine microphytobenthic assemblages along a gradient of light and nutrient availability in Suva Lagoon, Fiji. Eur. J. Phycol. 37, 449-462. doi: 10.1017/s0967026202003785

Van Cappellen, P., and Wang, Y. (1996). Cycling of iron and manganese in surface sediments; a general theory for the coupled transport and reaction of carbon, oxygen, nitrogen, sulfur, iron, and manganese. Am. J. Sci. 296, 197-243. doi: 10.2475/ajs.296.3.197

Wabete, N., Lemonnier, H., Barri, K., Pham, D., Boulo, V., Royer, F., et al. (2015). "Orange gills in Litopenaeus stylirostris: a new phenomenon in caledonian shrimp ponds," in Proceeding of the Aquaculture Fisheries conference, 20-22 July, Brisbane.

White, C., Sayer, J. A., and Gadd, G. M. (1997). Microbial solubilization and immobilization of toxic metals: key biogeochemical processes for treatment of contamination. FEMS Microbiol. Rev. 20, 503-516. doi: 10.1111/j.1574-6976. 1997.tb00333.x 
Wilkin, R. T., Arthur, M. A., and Dean, W. E. (1997). History of watercolumn anoxia in the Black Sea indicated by pyrite framboid size distributions. Earth Planet. Sci. Lett. 148, 517-525. doi: 10.1016/s0012-821x(97) 00053-8

Yücel, M., Konovalov, S. K., Moore, T. S., Janzen, C. P., and Luther, G. W. (2010). Sulfur speciation in the upper Black Sea sediments. Chem. Geol. 269, 364-375. doi: 10.1016/j.chemgeo.2009.10.010

Zbinden, M., Le Bris, N., Gaill, F., and Compère, P. (2004). Distribution of bacteria and associated minerals in the gill chamber of the vent shrimp Rimicaris exoculata and related biogeochemical processes. Mar. Ecol. Prog. Ser. 284, 237-251. doi: 10.3354/meps 284237
Conflict of Interest: The authors declare that the research was conducted in the absence of any commercial or financial relationships that could be construed as a potential conflict of interest.

Copyright (c) 2021 Lemonnier, Royer, Caradec, Lopez, Hubert, Rabiller, Desclaux, Fernandez and Andrieux-Loyer. This is an open-access article distributed under the terms of the Creative Commons Attribution License (CC BY). The use, distribution or reproduction in other forums is permitted, provided the original author(s) and the copyright owner(s) are credited and that the original publication in this journal is cited, in accordance with accepted academic practice. No use, distribution or reproduction is permitted which does not comply with these terms. 